\author{
Alicja SUMOWSKA \\ https://orcid.org/0000-0003-0510-7395 \\ Muzeum Okręgowe w Toruniu \\ Marcin SUMOWSKI \\ https://orcid.org/0000-0001-8012-1627 \\ Uniwersytet Mikołaja Kopernika w Toruniu
}

\title{
Średniowieczne rachunki kościoła Świętojańskiego w Toruniu. Uwagi źródłoznawcze*
}

Zarys treści: W artykule omówione zostały średniowieczne rachunki kościoła św. Jana w Toruniu pochodzące z XV i pierwszej połowy XVI w. Składa się na nie osiem jednostek archiwalnych przechowywanych w Archiwum Państwowym w Toruniu. Zaprezentowano ich budowę, treść, twórców oraz organizację wpisów. Omówiono także zależności między nimi a księgami miejskimi Torunia.

\begin{abstract}
The article discusses medieval accounts of St John's Church in Torun from the $15^{\text {th }}$ and the first half of the $16^{\text {th }}$ century. This set of financial records is made up of eight archival units kept in the State Archives in Torun. The article describes their structure, content, authors and arrangement of the entries; there is also a presentation of the relationship between these accounts and municipal records of the town of Torun.
\end{abstract}

Słowa kluczowe: średniowiecze, źródła rachunkowe, kościół św. Jana w Toruniu, fabrica ecclesiae, Toruń, Archiwum Państwowe w Toruniu

Keywords: Middle Ages, accounting sources, St John's Church in Toruń, fabrica ecclesiae, Toruń, State Archive in Toruń

We wstępie do księgi czynszowej kościoła Świętojańskiego w Toruniu (Liber censuum ecclesiae sancti Johannis) $)^{1}$, prowadzonej od 1468 r., rajcy miejscy wyrazili troskę o podupadły budynek świątyni. W związku z potrzebami budowlanymi wybrano kilku mieszczan do pomocy witrykowi w egzekwowaniu wpisanych do wspomnianej księgi zobowiązań czynszowych wobec kościoła². Rejestrowaniu

* Artykuł powstał w ramach realizacji projektu „Średniowieczne rachunki kościołów toruńskich - opracowanie, edycja, digitalizacja", sfinansowanego ze środków Narodowego Centrum Nauki przyznanych na podstawie decyzji nr DEC-2016/23/B/ HS3/00751. Autorzy są wykonawcami w tym projekcie.

1 Źródło łączy w sobie funkcje księgi czynszowej jako wykazu zobowiązań oraz rejestru czynszowego jako wykazu wpłat, ale ze względu na nadany jej przez pisarza tytuł będziemy określać ją księgą czynszową.

${ }^{2}$ AP Toruń, Kościół św. Jana, sygn. 8, k. 1v: „In der jorczal Ihesu Christi unnsers herren tawsint virhunderth unnd achtunndsechczigisten hot der ersame rath mit den eldisten herren vleyssiglich betracht unnd zu herczen genomen der kirchen sinte Johannis abenemen unnd vorterbnis unnd wie sie wedir uffkomen unnd gebawet moge werden. Dorummb hot der ersame rath dirkant etliche erbare gutte lewte us der gemeynen dovor zurathen unnd zukiesen neben dem herren des rathis alse dem ersamen herren Johan Rawsen disz iors kirchenvater unnd also vordan alle ior mit hulfe unnd bey stendikeit des herren us dem rathe vor dy kirche unnd ire czinser zurathen unnd dy zuvorsorgen. So sint gekoren dese erbaren nachgeschrebene gutte manne alse her Mattis Richter scheppe, Ludwig Schindeler unnd Liborius Iode unnd en sint der kirchen czinser obirandwert in desem buche geschreben". 
zarówno czynszów, jak i innych przychodów oraz wydatków służyły właśnie rachunki, dobrze zachowane dla toruńskiej świątyni. O ich szczególnej wartości decyduje niewielka dla ziem polskich ilość zachowanych materiałów rachunkowych dotyczących średniowiecznych kościołów parafialnych. W literaturze wspomina się o rachunkach kościoła św. Elżbiety we Wrocławiu z lat 1481-1522 czy świątyni w Luborzycy z lat 1507-15183. Warto zwrócić też uwagę na późniejsze rachunki kościoła w Zatorze z lat 1559-1561 ${ }^{4}$. Tymczasem rachunki toruńskie są dość liczne i obejmują stosunkowo długi chronologicznie okres (lata 20. XV w. - połowa XVI w.). Celem niniejszego artykułu jest ich prezentacja oraz wskazanie kilku uwag źródłoznawczych, sformułowanych w toku prac edytorskich i analizy tych źródeł5. Mają one charakter ogólny. Szczegółowe dane na temat tych źródeł znajdą się w planowanej w ramach projektu publikacji książkowej oraz edycji elektronicznej ${ }^{6}$.

Źródła o charakterze rachunkowym cieszą się sporym zainteresowaniem historyków ${ }^{7}$. Prawdopodobnie wpływa na to możliwość ich wykorzystywania w różnych badaniach, jak również przekonanie o większej „obiektywności” tego rodzaju rejestrów. Rachunki świątyń są szczególnie wartościowe z perspektywy studiów nad funkcjonowaniem parafii. To właśnie te źródła posłużyły Arndowi Reitemeierowi do opracowania obszernego studium na temat miejskiego kościoła parafialnego ${ }^{8}$. Źródła rachunkowe o charakterze kościelnym wykorzystywane są również do badania pobożności ${ }^{9}$ czy życia codziennego parafii ${ }^{10}$. Studiom tym często towarzyszą edycje ${ }^{11}$.

Stosunkowo duża liczba rachunków kościołów zachowała się dla średniowiecznych Prus ${ }^{12}$. Niektóre z nich były już przedmiotem zabiegów edytorskich. Do tej pory wydano choćby księgę parafialną z Reszla ${ }^{13}$,

${ }^{3}$ Zob. E. Knapek, Rachunki wikariuszy wieczystych katedry krakowskiej z lat 1493-1495 i 1497-1498, St. Źródł., 52, 2014, s. 115; por. I. Skierska, Zarząd finansami parafii w późnośredniowiecznej Polsce, „Ecclesia. Studia z Dziejów Wielkopolski”, 8, 2013, s. 15.

${ }^{4}$ P. Stanko, Rachunki kościoła parafialnego w Zatorze z lat 1559-1561, „Folia Historica Cracoviensia”, 18, 2012, s. $179-192$.

${ }_{5}$ Por. M. Grulkowski, Najstarsze księgi gruntowe Głównego Miasta Gdańska w XIV i XV wieku. Uwagi źródłoznawcze, w: Miasta polskie w średniowieczu i czasach nowożytnych, red. P. Gołdyn, Kraków 2008, s. 181-200.

${ }^{6}$ Edycja wraz z bazą danych zostanie udostępniona na stronie: <http://rachunki.tnt.torun.pl/> [dostęp: 6.04.2020].

${ }^{7}$ Zob. choćby tomy studiów: Editionswissenschaftiches Kolloquium 2009. Zahlen und Erinnerung: Von der Vielfalt der Rechnungsbücher und vergleichbarer Quellengattungen, wyd. H. Flachenecker, J. Tandecki, Torun 2010; Wirtschafts- und Rechnungsbücher des Mittelalters und der Frühen Neuzeit Formen und Methoden der Rechnungslegung: Städte, Klöster, Kaufleute, red. G. Gleba, N. Petersen, Göttingen 2015; Konzeptionelle Überlegungen zur Edition von Rechnungen und Amtsbüchern des späten Mittelalters, red. J. Sarnowsky, Hamburg 2016.

${ }^{8}$ A. Reitemeier, Pfarrkirchen in der Stadt des späten Mittelalters: Politik, Wirtschaft und Verwaltung, Wiesbaden 2005, autor poświęcił obszerny rozdział księgom rachunkowym kościołów jako źródłom historycznym (s. 33-88); zob. też J. Kahleyß, Die Kirchenrechnungen der Zwickauer Kirche St. Marien (1441-1534). Edition und Analyse ausgewählter Rechnungen, Dresden 2016.

9 Zob. np. A.J. Gornig, Die Rechnungen der Wittenberger Bruderschaften als Quellen zur vorreformatorischen Frömmigkeitsgeschichte, w: Alltag und Frömmigkeit am Vorabend der Reformation in Mitteldeutschland. Wissenschaftlicher Begleitband zur Ausstellung ,, Umsonst ist der Tod”, red. E. Bünz, H. Kühne, Leipzig 2015, s. 227-280; M. Ludwig, Frömmigkeitspraxis am Naumburger Dom um 1500 am Beispiel der Rechnungsquellen, w: tamże, s. 281-306.

10 Zob. np. F. Fuchs, Spätmittelalterliche Pfarrbücher als Quellen für die dörfliche Alltagsgeschichte, w: Die Pfarrei im späten Mittelalter, red. E. Bünz, G. Fouquet, Ostfildern 2013, s. 213-232.

${ }_{11}$ Zob. np. M. Prietzel, Alterleute und Kastenherren. Die Rechnungen der Kirche St. Jacobi in Göttingen von 1523/24 und 1534, „Göttinger Jahrbuch”, 41, 1993, s. 61-95; Die Finanzen eines spätmittelalterlichen Stadtpfarrers. Das Rechnungsbuch des Johann Hovet, Pfarrer von St. Johannis in Göttingen, für das Jahr 1510/11, red. M. Prietzel, Hannover 1994; P. Stanko, Rachunki kościoła, s. 179-192. Por. uwagi o edycji źródeł rachunkowych: M. Słoń, Blisko źródła czy Czytelnika? Refleksje na marginesie edycji rachunków szpitalnych z 1495 roku, St. Źródł., 45, 2007, s. 65-70.

12 Rachunkowość prowadzono choćby dla kościoła Mariackiego w Gdańsku: E. Kizik, Historisches Kirchen Register - opis autografu oraz jego źródet, w: Chronik der Marienkirche in Danzig. Das „Historische Kirchen Register” von Eberhard Bötticher (1616). Transkription und Auswertung / Kronika kościoła Mariackiego w Gdańsku. „Historisches Kirchen Register” Eberharda Böttichera (1616). Transkrypcja i analiza, red. Ch. Herrmann, E. Kizik, Köln-Weimar-Wien 2013, s. 304 n.; zob. też Ch. Herrmann, Witrycy kościoła Mariackiego w Gdańsku. Pozycja, zadania i działalność od XIV do początku XVII w., w: tamże, s. 159, 161.

${ }_{13}$ Das Rößeler Pfarrbuch. Aufzeichnungen der Kirchenväter an der Pfarrkirche zu Rößelin den Jahren 1442 bis 1614, wyd. G. Matern, A. Birch-Hirschfeld, Braunsberg 1937. 
księgę czynszową parafii w Chełmnie ${ }^{14}$ oraz spis czynszów wikarii w Młynarach ${ }^{15}$. Dotąd nieopublikowane pozostają natomiast prywatne rachunki Andreasa Sandberga - plebana w Brodnicy z lat 1439-1445 ${ }^{16}$ czy też niedatowane rachunki parafii w Młynarach ${ }^{17}$. Pod względem rejestrów dotyczących spraw kościelnych Toruń może poszczycić się całkiem pokaźną liczbą materiałów. Zachowały się rachunki nowomiejskiego kościoła św. Jakuba oraz filialnej wobec niego kaplicy św. Katarzyny z 1468 r. ${ }^{18}$, a także kościoła św. Wawrzyńca - filii parafii Świętojańskiej ${ }^{19}$. Wspomnieć należy również o prywatnych rachunkach staromiejskiego plebana Johanna van Ast z lat $1445-1446^{20}$. Najliczniejsze są jednak materiały dotyczące kościoła św. Jana.

Kościół parafialny dla Torunia został wymieniony już w przywileju chełmińskim z 1233 r., na mocy którego miasto powstało ${ }^{21}$. Prawo patronatu nad świątynią posiadał władca terytorialny, a zatem najpierw zakon niemiecki, później król Polski (od 1505 r. naprzemiennie z radą miejską) $)^{22}$. To mieszczanie byli jednak odpowiedzialni za budowę i późniejszą przebudowę świątyni, na co wskazują analizowane materiały rachunkowe. Kościół powstawał w kilku fazach, z czego ostatni etap przypadł na wiek XV²3. Jest on udokumentowany w prezentowanych tu źródłach.

W przypadku kościoła Świętojańskiego w Toruniu mamy do czynienia z 8 jednostkami archiwalnymi, które można określić mianem źródeł rachunkowych (zob. tab. 1). Mimo zróżnicowania w budowie i treści mieszczą się one w definicji ksiąg rachunkowych, rozumianych jako pisemne zestawienia przychodów i wydatków, powstałe celem sprawozdania i wynikające z relacji między sprawozdawcą a odbiorcą ${ }^{24}$. Jak wskazują dawne sygnatury, omawiane materiały znajdowały się wcześniej w zasobie biblioteki rady (Thorner Rathsbibliothek). Zapewne, podobnie jak księgi ławnicze, zostały stamtąd przeniesione do Archiwum Miejskiego w drugiej połowie XIX w. ${ }^{25}$, gdzie otrzymały nowe sygnatury i znalazły się w zespole Kat. II, w dziale XVII. Rechnungen von den Stadt- und Landkirchen ${ }^{26}$. Obecnie są one przechowywane w Archiwum Państwowym w Toruniu, w zespole Kościół św. Jana ${ }^{27}$.

Rachunki kościoła Świętojańskiego zostały spisane na papierze ${ }^{28}$. Występuje w nich tylko jedna karta pergaminowa, wtórnie dołączona i zawierająca XIV-wieczny spis czynszowy ${ }^{29}$. Jak wspominaliśmy,

${ }^{14}$ Księga czynszów fary chetmińskiej (1435-1496), wyd. Z.H. Nowak, J. Tandecki, Toruń 1994.

15 J. Sarnowsky, Die wirtschaftliche Lage der Pfarreien im Deutschordensland Preussen. Das Beispiel der Vikare zu Mühlhausen, w: Vera lex historiae. Studien zu mittelalterlichen Quellen. Festschrift für Dietrich Kurze zum 65. Geburtstag am 1. Januar 1993, red. S. Jenks, J. Sarnowsky, M.L. Laudage, Wien 1993, s. 373-420.

${ }^{16}$ Geheimes Staatsarchiv Preußischer Kulturbesitz Berlin-Dahlem, XX. Hauptabteilung, Ordensbriefarchiv, nr 9026.

17 Tamże, nr 28751.

${ }^{18}$ Edycja: M. Sumowski, Rachunki witryka kościoła św. Jakuba w Toruniu z 1468 roku, w: Parafie w średniowiecznych Prusach w czasach zakonu niemieckiego od XIII do XVI w., red. A. Radzimiński, R. Biskup, Toruń 2015, s. 237-271.

19 AP Toruń, Kat. I, sygn. 626/1/6-8; 834a.

${ }^{20}$ Edycja: A. Radzimiński, Rachunki plebana kościoła parafialnego Świętych Janów w Starym Mieście Toruniu z lat 1445-1446, Rocz. Hist., 69, 2003, s. 167-187; zob. też tenże, Piętnastowieczne rachunki plebanów z Torunia i Brodnicy jako źródta do badania dziejów parafii w państwie zakonu krzyżackiego w Prusach, Rocz. Hum., 48, 2000, nr 2, s. 473-482.

${ }^{21}$ Zob. W. Rozynkowski, Powstanie i rozwój sieci parafialnej w diecezji chelmińskiej w czasach panowania zakonu krzyżackiego, Torun 2000, s. 64-66.

22 Tenże, Patronat nad parafiami w średniowiecznej diecezji chetmińskiej, Rocz. Hum., 49, 2001, nr 2, s. 113-126, 137 n.

${ }^{23}$ Na temat dziejów, architektury i sztuki kościoła zob. Dzieje i skarby kościoła świętojańskiego w Toruniu, red. K. Kluczwajd, M. Woźniak, Torun 2002; Bazylika katedralna Świętych Janów w Toruniu, red. M. Biskup, Torun 2003; Kościót Świętojański w Toruniu: nowe rozpoznanie, red. K. Kluczwajd, Torun 2015.

${ }^{24}$ Definicja Marka Mersiowsky’ego, za: A. Reitemeier, Pfarrkirchen in der Stadt, s. 33.

${ }^{25}$ Zob. AP Toruń, Inwentarz zespołu (zbioru) akt: Akta kościołów i parafii diecezji chełmińskiej z lat 1380-1939, oprac. K. Ciesielska, Toruń 1973, s. 9; Księga ławnicza Starego Miasta Torunia (1428-1456), cz. 1: 1428-1443, wyd. K. Ciesielska, J. Tandecki, Toruń 1992, s. XIX n.

${ }^{26}$ AP Toruń, Catalog II des Raths-Archivs zu Thorn: Gebundene \& geheftete Handschriften, auch Karten, Pläne \& Abbildungen, s. $64 \mathrm{n}$.

27 AP Toruń, Inwentarz zespołu (zbioru) akt: Akta kościołów i parafii diecezji chełmińskiej z lat 1380-1939, oprac. K. Ciesielska, Torun 1973, s. 41 n.

28 Por. A. Reitemeier, Pfarrkirchen in der Stadt, s. 38.

${ }^{29}$ AP Toruń, Kościół św. Jana, sygn. 6, s. 83 n. Spis datowany jest na ok. 1380 r.; AP Toruń, Inwentarz zespołu (zbioru) akt: Akta kościołów i parafii diecezji chełmińskiej z lat 1380-1939, oprac. K. Ciesielska, Toruń 1973, s. 41. 
źródła te cechuje duże zróżnicowanie. Tylko dwie jednostki (sygn. 8, 12) można uznać za materiały powstałe pierwotnie jako księgi ${ }^{30}$. Posiadają one oryginalne oprawy (sygn. 8 - pergamin, sygn. 12 skóra), wyróżniają się regularnością składek oraz występowaniem tych samych lub podobnych znaków wodnych w obrębie całej jednostki. Dla przykładu, w sygn. 8 występują znaki wodne przedstawiające głowę wołu w dwóch wariantach ${ }^{31}$. Ponadto jako jedyna ma oryginalny, nadany w XV w. tytuł, zapisany na pergaminowej oprawie. Obie jednostki sporządzono w formacie folio, zostały też oznaczone marginesami i w niektórych partiach poliniowane. Ich treść zorganizowano w sposób zakładający długotrwałe użytkowanie. Jest to szczególnie zauważalne w sygn. 12. Cała księga liczy 234 karty, ale zapisane zostało tylko pierwsze 120 .

Być może do ksiąg w sensie ścisłym należałoby zaliczyć również sygn. 9. Ma ona format dutki o dość regularnym układzie składek, jednakowym wymiarze kart oraz tym samym znaku wodnym w obrębie całości (dzwon) ${ }^{32}$. Jej treść stanowią wpisy o spójnej tematyce, których ułożenie przewidywało kilkuletnie funkcjonowanie. Nie ma ona jednak oryginalnej oprawy. W XIX w. została oprawiona w niebieski karton, podobnie jak pozostałe rachunki. Stanowią one wtórnie połączone składki, najczęściej mające format dutki (sygn. 7, 10, 13). Czasem poszczególne składki różnią się rozmiarem kart (sygn. 7, 10), a nawet zawierają własną, równoległą do całości paginację (np. sygn. 7: k. 41r, rozpoczynająca składkę, jest numerowana starszą, przekreśloną paginacją jako k. 1r; sygn. 10: k. 69r, rozpoczynająca składkę, jest numerowana starszą paginacją jako k. 1r). Największe różnice wymiarów występują w sygn. 6 , gdzie połączone zostały składki w formacie dutki, folio, a także pojedyncze karty papierowe. Do fascykułu doszyta została również wspomniana wyżej karta pergaminowa. Składki w niektórych jednostkach (sygn. 6,7,10) zapewne pierwotnie funkcjonowały samodzielnie. Zawarte w nich wpisy są bowiem spójne tematycznie i chronologicznie, czego brakuje jednak w obrębie całej jednostki. Stan ten odzwierciedlają także znaki wodne, różne dla poszczególnych składek. Jest to dobrze widoczne w sygn. 7. W pierwszej składce, datowanej na lata 30. XV w., występuje znak przedstawiający jelenia $^{33}$, w drugiej (ok. 1470 r.) - głowy wołu w dwóch wariantach ${ }^{34}$, z kolei składki od trzeciej do piątej (przełom XV i XVI w.) - koło młyńskie ${ }^{35}$. Ponadto w każdej z jednostek wyróżnić można co najmniej po kilka rąk pisarskich. Charakterystyczne jest również występowanie tej samej ręki w kilku różnych jednostkach (zob. niżej). Nieco odmienną budową charakteryzuje się sygn. 11. Tworzy ją w zasadzie jedna obszerna składka folio (s. 1-114), do której dodano trzy mniejsze. Całość została spisana jedną ręką i jest spójna tematycznie. Zmiany znaków wodnych występują między poszczególnymi składkami. Są one jednak podobne (głowa wołu), ale w różnych wariantach. Wyjątek stanowi doklejony wewnątrz składki pierwszej arkusz (s. 25-28), późniejszy w stosunku do sąsiadujących wpisów.

Omawiane źródła są zróżnicowane tematycznie. Znajdziemy wśród nich rejestry czynszowe z miasta i kościelnej wsi Siemoń, wykazy przychodów (z pogrzebów, ofiar etc.) i wydatków (zob. il. 1), rachunki budowlane, rozliczenia witryków z radą miejską, inwentarze wyposażenia czy ordynację dla dzwonników (zob. niżej). Dzięki temu dają możliwość poznania zarówno różnych aspektów funkcjonowania

\footnotetext{
${ }^{30}$ Zob. rozważania nad definicją ksiąg miejskich: M. Grulkowski, Definicja i klasyfikacje ksiag miejskich. Księgi w kancelariach miast obszaru Hanzy, w: Nauki pomocnicze historii. Teoria, metody badań, dydaktyka, red. A. Jaworska, R. Jop, Warszawa 2013, s. 119-148; por. M. Słoń, Średniowieczne rachunki szpitali wrocławskich, Kwart. Hist., 105, 1998, nr 2, s. 26.

31 Zob. filigrany pokrewne: Wasserzeichen-Informationssystem $<$ https://www.wasserzeichen-online.de/wzis/struktur.php?klassi=002007004002001001003002\&anzeigeIDMotif=13173>; <https:/www.wasserzeichen-online.de/wzis/struktur.php?re$\mathrm{f}=\mathrm{AT} 3800-\mathrm{PO}-70405>$ [dostęp: 9.04.2020].

32 Zob. filigrany pokrewne: Wasserzeichen-Informationssystem $<$ https://www.wasserzeichen-online.de/wzis/struktur.php?klassi=006009001001001001\&anzeigeIDMotif=11242> [dostęp: 9.04.2020].

${ }_{33}$ Zob. filigrany pokrewne: Wasserzeichen-Informationssystem $<$ https://www.wasserzeichen-online.de/wzis/struktur.php?klassi=002001008002\&anzeigeIDMotif=2627> [dostęp: 10.04.2020].

${ }_{34}$ Zob. filigrany pokrewne: Wasserzeichen-Informationssystem <https://www.wasserzeichen-online.de/wzis/struktur.php?klas si $=002007004001002001006 \&$ anzeigeIDMotif $=13117>;<$ https://www.wasserzeichen-online.de/wzis/struktur.php?klassi $=0$ 02007002003006002001006\&anzeigeIDMotif=12863> [10.04.2020].

${ }^{35}$ Zob. filigrany pokrewne: Wasserzeichen-Informationssystem $<\mathrm{https}$ ://www.wasserzeichen-online.de/wzis/struktur.php?klas $\mathrm{si}=006003015001 \&$ anzeigeIDMotif $=5881>$ [dostęp: 10.04.2020].
} 
Tabela 1. Średniowieczne rachunki kościoła Świętojańskiego w Toruniu

\begin{tabular}{|c|c|c|c|c|c|c|}
\hline Lp. & Sygnatura & Sygnatury dawne & Okres & $\begin{array}{c}\text { Liczba } \\
\text { kart/stron }\end{array}$ & Format & Treśćc \\
\hline 1. & $\begin{array}{l}\text { AP Toruń, Kościół } \\
\text { św. Jana, sygn. } 6^{36}\end{array}$ & $\begin{array}{l}\text { Lit. A fol. No. 139a; } \\
\text { Kat. II, XVII } 44\end{array}$ & $\begin{array}{l}1436-1553 \\
(\text { karta } \\
\text { pergaminowa } \\
- \text { ok. } 1380 \mathrm{r} .)\end{array}$ & 160 stron & $\begin{array}{l}\text { dutka/ } \\
\text { folio }\end{array}$ & $\begin{array}{l}\text { inwentarz ołtarza; przychody } \\
\text { i wydatki; czynsze ze wsi } \\
\text { Siemoń }\end{array}$ \\
\hline 2. & $\begin{array}{l}\text { AP Toruń, Kościół } \\
\text { św. Jana, sygn. } 7^{37}\end{array}$ & $\begin{array}{l}\text { Lit. A fol. No. 138a; } \\
\text { Kat. II, XVII } 41\end{array}$ & $1420-1502$ & 67 kart & dutka & $\begin{array}{l}\text { rachunki budowlane; } \\
\text { wynagrodzenia; przychody } \\
\text { i wydatki; czynsze ze wsi } \\
\text { Siemoń }\end{array}$ \\
\hline 3. & $\begin{array}{l}\text { AP Toruń, Kościół } \\
\text { św. Jana, sygn. } 8\end{array}$ & $\begin{array}{l}\text { Lit. A fol. No. 261; } \\
\text { Scrin. XIV No. 1; } \\
\text { Scrin XVII 28; Kat. II, } \\
\text { XVII } 42\end{array}$ & $1468-1525$ & 94 karty & folio & $\begin{array}{l}\text { księga czynszowa (czynsze } \\
\text { w obrębie miasta) }\end{array}$ \\
\hline 4. & $\begin{array}{l}\text { AP Toruń, Kościół } \\
\text { św. Jana, sygn. } 9\end{array}$ & Kat. II, XVII 46 & $1469-1525$ & 72 karty & dutka & $\begin{array}{l}\text { przychody i wydatki; rachunk } \\
\text { budowalne; czynsze ze wsi } \\
\text { Siemoń }\end{array}$ \\
\hline 5. & $\begin{array}{l}\text { AP Toruń, Kościół } \\
\text { św. Jana, sygn. } 10\end{array}$ & Kat. II, XVII 43 & $1500-1527$ & 126 kart & dutka & $\begin{array}{l}\text { przychody i wydatki; czynsze; } \\
\text { ordynacja dla dzwonników }\end{array}$ \\
\hline 6. & $\begin{array}{l}\text { AP Toruń, Kościół } \\
\text { św. Jana, sygn. } 11\end{array}$ & $\begin{array}{l}\text { Lit. A fol. No. 269a; } \\
\text { Kat. II, XVII } 45\end{array}$ & $1509-1520$ & 152 karty & folio & $\begin{array}{l}\text { przychody i wydatki; zakup } \\
\text { wosku }\end{array}$ \\
\hline 7. & $\begin{array}{l}\text { AP Toruń, Kościół } \\
\text { św. Jana, sygn. } 12\end{array}$ & $\begin{array}{l}\text { Lit. A fol. No. 139; } \\
\text { Kat. II, XVII } 47\end{array}$ & $1520-1553$ & 234 karty & folio & przychody i wydatki \\
\hline 8. & $\begin{array}{l}\text { AP Toruń, Kościół } \\
\text { św. Jana, sygn. } 13\end{array}$ & $\begin{array}{l}\text { Lit. A fol. No. } 331 \text {; } \\
\text { Kat. II, XVII } 48\end{array}$ & $1546-1553$ & 94 karty & dutka & $\begin{array}{l}\text { przychody i wydatki; } \\
\text { inwentarz kościoła }\end{array}$ \\
\hline
\end{tabular}

późnośredniowiecznej parafii miejskiej, jak również zagadnień związanych z socjotopografią Torunia, genealogią i prozopografią mieszczan, urzędami miejskimi, fundacjami, a także dziejami kościoła Świętojańskiego w kontekście archeologii i historii sztuki. Jak dotąd były jednak wykorzystywane w bardzo ograniczonym zakresie ${ }^{38}$. Być może było to wynikiem uznawania ich za źródła o wyłącznie kościelnym charakterze.

Dotychczasowa historiografia istotnie nie wliczała omawianych tu źródeł do kategorii rachunków miejskiej proweniencji ${ }^{39}$. Badacze wśród ksiąg miejskich wymieniali wspominaną wyżej księgę czynszową kościoła parafialnego w Chełmnie, którą wydawcy uznali za ,jedyną zachowaną średniowieczną księgę witryków" ${ }^{40}$. Tym samym pominięto analogiczne źródło dotyczące kościoła św. Jana w Toruniu (sygn. 8), czego przyczyną było zapewne przyjęcie określonych ram chronologicznych ${ }^{41}$. Wydaje się jednak, że w przypadku kościelnej rachunkowości to dopiero wraz z reformacją można mówić o końcu epoki. Być może nieprzypadkowo omawiane źródła kończą się na połowie XVI w., a kolejne pochodzą

${ }^{36}$ Fragment został wydany: A. Semrau, Der Bau des Kirchturms zu S. Johann in Thorn, „Mitteilungen des Coppernicus-Vereins für Wissenschaft und Kunst zu Thorn", 18, 1910, s. 31.

37 Fragmenty zostały wydane: tamże, s. 31-39.

38 Zob. A. Semrau, Forschungen zur Baugeschichte der Johanniskirche in Thorn von 1250 bis 1500, „Mitteilungen des Coppernicus-Vereins für Wissenschaft und Kunst zu Thorn", 21, 1913, nr 2, s. 28-53.

39 J. Tandecki, Średniowieczne księi wielkich miast pruskich jako źródta historyczne i zabytki kultury mieszczańskiej (organizacja władz, zachowane archiwalia, działalność kancelarii), Warszawa-Torun 1990, s. 143-164; tenże, Średniowieczne księgi rachunkowe Starego Miasta Torunia i ich edycje, w: tenże, Szkice z dziejów Torunia i Prus w średniowieczu i na progu czasów nowożytnych, Toruń 2008, s. 103-117; M. Grulkowski, Najstarsze księgi miejskie Głównego Miasta Gdańska z XIV i poczatku XV wieku. Studium kodykologiczne, Warszawa 2015, s. 23-26; por. A. Bartoszewicz, Piśmienność mieszczańska w późnośredniowiecznej Polsce, Warszawa 2012, s. 105-107.

${ }^{40}$ Księga czynszów fary chetmińskiej, s. XI.

${ }^{41}$ J. Tandecki, Średniowieczne księgi wielkich miast pruskich, s. 102; M. Grulkowski, Najstarsze księgi miejskie, s. 29. 


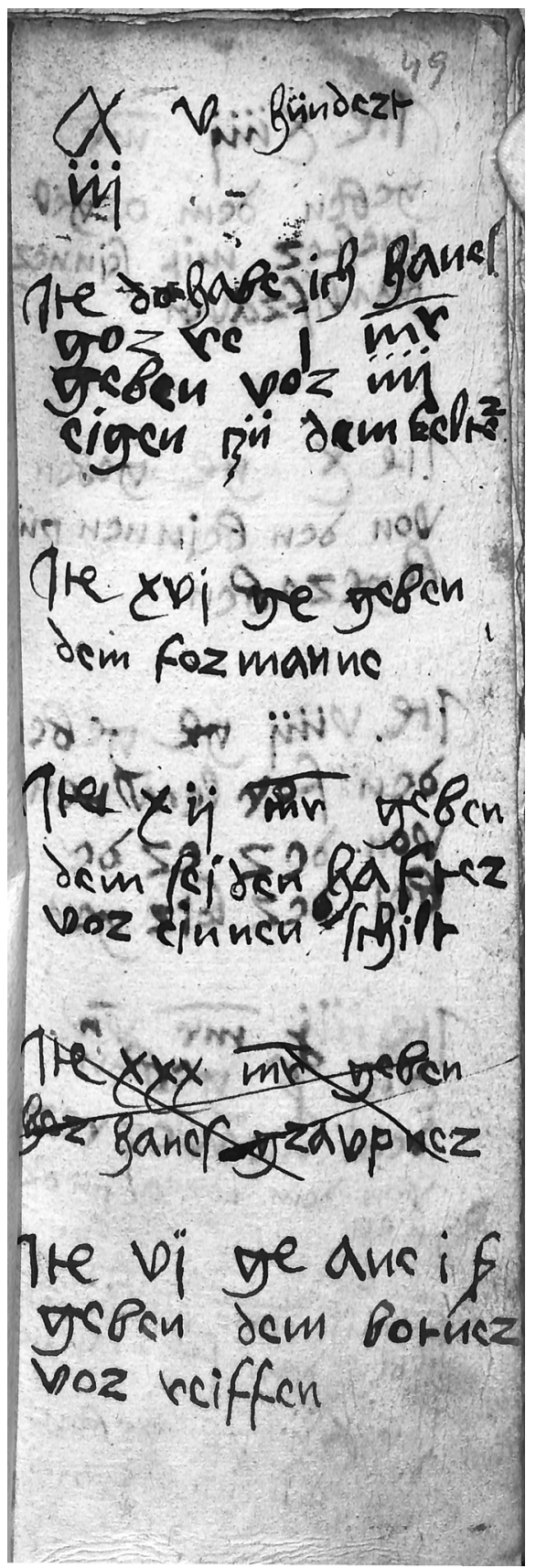

Il. 1. Wydatki z 1503 r. - dukt pisma Hansa Gore; AP Toruń, Kościół św. Jana, sygn. 6, s. 49

dopiero z XVII stulecia ${ }^{42}$. Zasadne jest zatem pytanie o miejski charakter analizowanych źródeł. Omawiane rachunki wiązały się z działalnością funduszu kościelnego (fabrica ecclesiae), oddzielonego od majątku plebana i przeznaczonego na potrzeby kościoła ${ }^{43}$. Funduszem tym zarządzali w Toruniu zależni od władz miejskich witrycy ${ }^{44}$. Przy kościele Świętojańskim funkcjonowało ich dwóch. W rachunkach

42 AP Toruń, Catalog II des Raths-Archivs zu Thorn: Gebundene \& geheftete Handschriften, auch Karten, Pläne \& Abbildungen, s. 65; AP Toruń, Inwentarz zespołu (zbioru) akt: Akta kościołów i parafii diecezji chełmińskiej z lat 1380-1939, oprac. K. Ciesielska, Torun 1973, s. 42.

43 Zob. I. Skierska, Zarząd finansami, s. 7 n.

${ }^{44}$ Dla Prus zob. Ch. Herrmann, Witrycy kościoła Mariackiego, s. 151-193; dla miast niemieckich: A. Reitemeier, Pfarrkirchen in der Stadt, s. 102-122; dla Polski ostatnio: I. Skierska, Zarzad finansami, s. 7-26. 
określani są jako kirchenvater ${ }^{45}$, kirchen stifftvatter ${ }^{46}$, vorweser und vorsorger ${ }^{47}$. Odpowiedź na pytanie o charakter rachunków kościoła jako źródeł miejskich leży częściowo w pytaniu o status witryków jako urzędników miejskich ${ }^{48}$. Toruńscy zarządcy kościołów byli w dotychczasowej historiografii jednoznacznie umieszczani wśród urzędników radzieckich ${ }^{49}$.

Nic nie wskazuje na to, aby pleban toruński brał udział w wyborze witryków. Zgadza się to z hipotezą Izabeli Skierskiej w odniesieniu do miast lokowanych na prawie niemieckim ${ }^{50}$. Uczestnictwo duchownego w wyborze postulowano wprawdzie w polskich statutach synodalnych ${ }^{51}$, ale normy diecezji pruskich milczą na ten temat ${ }^{52}$. Regulacji dotyczących witryków nie znajdziemy w najstarszych znanych statutach diecezji chełmińskiej, do której należał Toruń, pochodzących z ok. $1438 \mathrm{r}^{53}$ Występują oni w statutach z 1481 i 1498 r., niedotyczących jednak sposobu ich wyboru i podległości ${ }^{54}$. Wydaje się, że obsada zarządców majątku kościelnego w Toruniu była wyłącznie decyzją rady miejskiej ${ }^{55}$. W 1479 r. w staromiejskiej księdze ławniczej witryk Heinrich Kruger został wprost określony jako wybrany przez radę (,von erssamen rathe gekoren”) ${ }^{56}$. W omawianych źródłach znajdują się z kolei wpisy informujące o wyborze nowych witryków bezpośrednio przez rajców z lat 1503 (29 listopa-

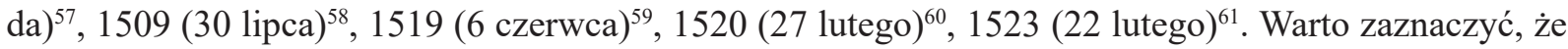
w dwóch odnotowanych przypadkach wybór odbył się w dniu Cathedra Petri (22 lutego), kiedy w Toruniu zwyczajowo odbywała się kiera ${ }^{62}$ : w 1517 (,uff die ko<e $>$ re am tage Petri Stu<e $>$ lfeyer") ${ }^{63}$ oraz 1523 r. („off dye kird”) ${ }^{64}$. Sugeruje to usytuowanie witryków w gronie urzędników miejskich. Zapisy wskazują ponadto, że wybór dotyczył tylko jednego z nich, podczas gdy drugi pozostawał aktualnie na stanowisku.

${ }^{45}$ Zob. AP Toruń, Kościół św. Jana, sygn. 8, k. 1v.

${ }_{46}$ Zob. tamże, sygn. 11, s. 3; tamże, sygn. 12, k. [0r].

${ }^{47}$ Zob. tamże, sygn. 9, k. 49r; tamże, sygn. 10, k. 69r.

48 Szczegółowe rozważania na temat toruńskich witryków znajdą się we wstępie do planowanej edycji.

49 J. Tandecki, Średniowieczne księgi wielkich miast pruskich, s. 32 n.; R. Czaja, Urzędnicy miejscy Torunia. Spisy, cz. 1: Do roku 1454, Toruń 1999, s. 25. Podobnie gdańscy: Ch. Herrmann, Witrycy kościoła Mariackiego, s. 160.

${ }^{50}$ I. Skierska, Zarząd finansami, s. 25. Por. sytuację w Nysie, gdzie również nie odnotowano udziału plebana w wyborze witryków: E. Wółkiewicz, Kościół i jego wierni. Struktury kościelne i formy pobożności w średniowiecznej Nysie, Kraków 2014, s. 164.

${ }^{51}$ S. Sołtyszewski, Geneza instytucji witrykusów w polskim ustawodawstwie synodalnym, „Prawo Kanoniczne”, 2, 1959, nr 1-2, s. 430-433; tenże, Powotywanie witrykusów w polskim ustawodawstwie synodalnym, „Prawo Kanoniczne”, 2, 1959, nr 3-4, s. 348-350; E. Wiśniowski, Udziat świeckich w zarzadzie parafia w średniowiecznej Polsce, Rocz. Hum., 18, 1970, nr 2, s. 55; tenże, Parafie w średniowiecznej Polsce. Struktura i funkcje społeczne, Lublin 2004, s. 176 n., 184; I. Skierska, Zarząd finansami, s. 13.

52 Constitutiones synodales Warmienses, Sambienses, Pomesanienses, Culmenses necnon provinciales Rigenses, wyd. F. Hipler, Brunsbergae 1899; por. thum. Statuty synodalne Warmińskie, Sambijskie, Pomezańskie, Chetmińskie oraz Prowincjalne Ryskie, tłum. J. Wojtkowski, Olsztyn 2010.

${ }^{53}$ Zostały one niedawno odnalezione: M. Czyżak, A. Radzimiński, Earliest Synod Statutes of John Marienau, Bishop of Chetmno, from the First Half of 15th Century, „Quaestiones Medii Aevi Novae”, 24, 2019, s. 111-135. Dotąd ich treść znana była jedynie z późniejszego skrótu niemieckojęzycznego: Constitutiones synodales necnon ordinationes dioecesis Culmensis, cz. 1, wyd. A. Mańkowski, „Fontes Towarzystwa Naukowego w Toruniu”, 24, 1929, s. 13-19.

${ }_{54}$ M. Czyżak, A. Radzimiński, Earliest Synod Statutes, s. 131 [nr 2], 133 [nr 11], 134 [nr 15].

55 Podobnie było w Gdańsku: Ch. Herrmann, Witrycy kościoła Mariackiego, s. 154, 158 n.

${ }^{56}$ Księga ławnicza Starego Miasta Torunia (1479-1515), cz. 1: 1479-1501, wyd. K. Kopiński, K. Mikulski, J. Tandecki, Toruń 2018, nr 21.

57 AP Toruń, Kościół św. Jana, sygn. 8, k. 16v.

58 Tamże, sygn. 11, s. 3.

59 Tamże, sygn. 9, k. 49r; tamże, sygn. 10, k. 69r.

${ }^{60}$ Tamże, sygn. 12, k. [0r].

${ }^{61}$ Tamże, k. 28r.

${ }^{62}$ M. Biskup, Historia Torunia, t. 2, cz. 1: U schyłku średniowiecza i w początkach odrodzenia (1454-1548), red. M. Biskup, Torun 1992, s. 87; J. Tandecki, Rozkwit toruńskiego ośrodka handlowego i produkcyjnego w latach 1350-1411, w: Historia Torunia, t. 1: W czasach średniowiecza (do roku 1454), red. M. Biskup, Toruń 1999, s. 180.

${ }^{63}$ AP Toruń, Kościół św. Jana, sygn. 8, k. 66v. W tym wypadku brak wzmianki o wybierających.

${ }^{64}$ Tamże, sygn. 12, k. 28r. 
Wygląda na to, że toruńscy witrycy odpowiadali wyłącznie przed radą miejską. $\mathrm{W}$ transakcjach związanych z funduszem kościelnym występowali w imieniu władz (,van des ersamen ratis wegen”) ${ }^{65}$, sporządzane rachunki przedkładali radzie do sprawozdania i to z nią się rozliczali ${ }^{66}$. Wpisy o zdawaniu rajcom rachunku pojawiły się choćby w $1491^{67}, 1500^{68}, 1501^{69}$ i 1508 r. $^{70}$ Warto dodać, że w $1501 \mathrm{r}$. witryk Nicolaus Kober składał swoje rachunki przed burmistrzami w ratuszu („off dem roth hawsze”). Nie ma natomiast dowodów na obecność plebana przy dokonywaniu rozliczen. Postulat jego udziału w zarządzie majątkiem kościoła pojawia się w źródłach pruskich, również w odniesieniu do sprawozdań finansowych ${ }^{71}$. Praktykowany był choćby w Reszlu, gdzie pleban występuje w rozliczeniach ${ }^{72}$. Rzeczywista partycypacja duchownych w zarządzie finansami kościoła miejskiego w Prusach zależała jednak raczej od indywidualnego ułożenia relacji z parafianami ${ }^{73}$. W dużym mieście pozycja duszpasterza względem silnej rady miejskiej musiała być zupełnie inna niż na wsi ${ }^{74}$, a władze miejskie niechętnie mogły godzić się na wgląd plebana w rachunki kościoła ${ }^{75}$.

Statuty diecezji chełmińskiej regulowały relacje witryków i plebana, ale w dość ograniczonym zakre$\mathrm{sie}^{76}$. Prawdopodobnie to do witryków odnosi się statut z $1481 \mathrm{r}$., stanowiący o przechowywaniu sakramentów, do których kluczy nie powinny posiadać osoby świeckie ${ }^{77}$. W 1498 r. wystąpili oni jako biorący udział w inwentaryzacji dóbr zmarłego plebana ${ }^{78}$. W tych samych statutach znajdziemy informację o roli plebana w zarządzie majątkiem kościoła. Miał on posiadać jeden z kluczy do pieniędzy kościoła, drugi dzierżyli zaś witrycy. Celem regulacji była wzajemna kontrola. Działania funduszu miały odbywać się zaś za wiedzą i radą plebana („scitu et consilio") ${ }^{79}$. Biskup chełmiński podobnie ujmował rolę duchownego już w dokumencie z 1361 r., zgodnie z którym toruńscy witrycy mieli działać za jego wiedzą (,,cum certa sciencia”) i radą („cum consilio”) ${ }^{80}$. Nie sposób jednak określić rzeczywistego wpływu duchownego na fundusz kościelny, a tym bardziej na powstałą w związku z nim rachunkowość. W omawianych źródłach pojawia się on głównie jako odbiorca należnych mu opłat pobieranych z pogrzebów i wydatkach na wosk ${ }^{81}$.

Nawet w najstarszych rachunkach nie da się zaobserwować wpływu na kościelną rachunkowość ani plebana, ani wcześniejszych patronów (zakon niemiecki, król Polski). Współgrało to z ich ograniczonym

${ }_{65}$ Zob. Księga ławnicza Starego Miasta Torunia (1428-1456), cz. 2: 1444-1456, wyd. K. Ciesielska, J. Tandecki, Toruń 1993, nr 1618; por. E. Wółkiewicz, Kościót i jego wierni, s. 165.

${ }^{66}$ Podobnie w Gdańsku: Ch. Herrmann, Witrycy kościoła Mariackiego, s. 161.

${ }^{67}$ AP Toruń, Kościół św. Jana, sygn. 8, k. 72r.

68 Tamże, sygn. 10, k. 1r.

69 Tamże, k. $17 \mathrm{v}$.

70 AP Torun, Kościół św. Jana, sygn. 6, s. 41.

${ }_{71}$ Zob. np. Constitutiones synodales Warmienses, kol. 286, 304 [Statuty synodalne, s. 260, 275]; O. Günther, Eine Predigt vom preußischen Provinzialkonzil in Elbing 1427 und die „Ermahnung des Carthäusers”, „Zeitschrift des Westpreussischen Geschichtsvereins”, 59, 1919, s. 99; ,Formularz z Uppsali”. Późnośredniowieczna księga formularzowa biskupstw pruskich, koment. i wyd. R. Biskup, Torun 2016, nr 430; E. Wiśniowski, Parafie, s. 178 n. Por. statuty ryskiej prowincji kościelnej z 1428 r., które nakładały na witryków odpowiedzialność za budynek świątyni, plebanowi przyznając rolę pomocniczą: Constitutiones synodales Warmienses, kol. 324-325 [Statuty synodalne, s. 292 n.].

72 Das Rößeler Pfarrbuch, s. 9, 37, 92 n., 95, 97.

${ }_{73}$ M. Sumowski, „Pastor et oves” - Parish Priest in Late-Medieval Prussian Town, „Quaestiones Medii Aevii Novae”, 23, 2018, s. 366-368. Szerzej w przygotowywanej do druku dysertacji M. Sumowskiego.

74 Por. przykład wsi Pluskowęsy pod Toruniem, gdzie to parafianie, bez udziału plebana i patrona, występowali w sprawach budowalnych swojego kościoła; S. Jóźwiak, Kościót parafialny w Pluskowęsach $w$ ziemi chetmińskiej $w$ świetle średniowiecznych źródet pisanych, w: Parafie w średniowiecznych Prusach, s. 135 n., 138.

75 Zob. sytuację w miastach śląskich: E. Wółkiewicz, Kościół i jego wierni, s. 169 n.

76 Statuty polskie dokładniej regulowały te kwestie: S. Sołtyszewski, Geneza instytucji, s. 433 n.; tenże, Prawa i obowiazki witrykusów w polskim ustawodawstwie synodalnym, „Prawo Kanoniczne”, 3, 1960, nr 1-2, s. 280, 284; E. Wiśniowski, Udziat świeckich, s. 55 n.; tenże, Parafie, s. 177 n.; I. Skierska, Zarzad finansami, s. 14.

77 M. Czyżak, A Radzimiński, Earliest Synod Statutes, s. 131 [nr 2].

78 Tamże, s. 133 [nr 11].

79 Tamże, s. 134 [nr 15]; por. S. Sołtyszewski, Prawa i obowiazki, s. 263, 270; E. Wiśniowski, Udziat świeckich, s. 63 n.; tenże, Parafie, s. 178 n.

${ }^{80}$ Urkundenbuch des Bisthums Culm, t. 1, oprac. C.P. Woelky, cz. 1, Danzig 1885, nr 308.

${ }^{81}$ Zob. np. AP Toruń, Kościół św. Jana, sygn. 10, k. 15v, 40r, 44r, 47r; tamże, sygn. 11, s. 2, 9, 18, 21, 22, 23, 99, 103, $104,132$. 
wpływem na miejskie kościoły parafialne na obszarze osadnictwa niemieckiego ${ }^{82}$. Kontrolowanie finansów przez radę miejską, która od 1505 r. naprzemiennie z królem patronowała kościołowi, nie wynikało z jej uprawnień patronackich, ale było efektem ogólnoeuropejskiego zjawiska tzw. komunalizacji kościołów ${ }^{83}$ oraz „ureligijnienia” miejskiej rzeczywistości publicznej ${ }^{84}$. „Miejski” charakter działalności witryka miał związek z odpowiedzialnością władz komunalnych za świątynię. Niekiedy przy współudziale plebana, niekiedy przeciw niemu, ale być może równie często bez jego większego udziału. Późnośredniowieczna miejska fabrica ecclesiae stawała się bogatą instytucją finansową ${ }^{85}$. Możemy zakładać, że w takich miastach jak Toruń witryk nie był funkcjonariuszem w równym stopniu odpowiedzialnym przed plebanem, patronem i parafianami. Działał między ich sprzecznymi niekiedy dążeniami ${ }^{86}$, ale traktowany był jako urzędnik miejski. Na obecnym etapie badań można przyjąć, że prowadzone przez niego rejestry należałoby traktować jako źródła miejskie. Zarówno w swojej formie, jak i treści są one podobne do rachunków innych miejskich urzędów. Wspólne były także ich losy jako archiwaliów. Sprawozdania finansowe urzędów również spisywano na składkach w formacie dutki, o wymiarach podobnych do omawianych rejestrów. Miały też układ wpisów podobny do wykazów przychodów i wydatków kościoła. Obecny kształt połączonych w jednostki składek przybrały dopiero w XIX w., niekiedy bez uporządkowania, co jest wyraźną cechą części omawianych tu źródeł (sygn. 6, $7,10)^{87}$. Biorąc pod uwagę powyższe rozważania, mamy raczej do czynienia z rachunkami „kościołów”, nie „kościelnymi”.

Podobnie jak niektórzy urzędnicy miejscy, witrycy prowadzili swoje rachunki osobiście ${ }^{88}$. Świadczą o tym liczne wpisy sporządzone w pierwszej osobie (,habe ich entfangen" ${ }^{89}$, „ich vorkoufft habe"90, „ich habe gegeben" ${ }^{91}$, „ich habe [...] beczalt" ${ }^{2}$, „habe ich [...] rechnunge gethon" ${ }^{3}$, „habe ich genomen"94), które piszący opatrywali niekiedy własnym nazwiskiem. Wśród podpisujących się witryków znajdziemy Nicolausa Kobera (witryka w latach 1495-1501) ${ }^{95}$, Hansa Gore (1502-1503) ${ }^{96}$, Martina Keszelinga (1503-1516) $)^{97}$, Caspara Schottdorffa $(1509-1520)^{98}$, Georga Sweczgke $(1517-1518)^{99}$,

${ }^{82}$ Ch. Herrmann, Witrycy kościoła Mariackiego, s. 152.

${ }^{83}$ Por. R. Czaja, Miasta pruskie a zakon krzyżacki. Studia nad stosunkami między miastem a władza terytorialnq w późnym średniowieczu, Toruń 1999, s. 46 n.

${ }^{84}$ Zob. H. Manikowska, Religijność miejska, w: Ecclesia et civitas. Kościót i życie religijne w mieście średniowiecznym, red. H. Manikowska, H. Zaremska, Warszawa 2002, s. 11-34; M. Słoń, Religijność komunalna w Europie środkowej późnego średniowiecza, w: Zbožnost středověku, red. M. Nodl, K. Bracha, J. Hrdina, P. Kras, Colloquia mediaevalia Pragensia, t. 6, Praha 2007, s. 9-21.

${ }^{85}$ Ch. Herrmann, Witrycy kościoła Mariackiego, s. 153, por. s. 165.

${ }^{86}$ Por. M. Sumowski, Rachunki witryka, s. 240.

87 J. Tandecki, Średniowieczne księgi wielkich miast pruskich, s. $152 \mathrm{n}$.

${ }_{88}$ Zob. tamże, s. 156-158.

${ }^{89}$ Zob. np. AP Toruń, Kościół św. Jana, sygn. 9, k. 1v; tamże, sygn. 11, s. 10.

90 Zob. np. tamże, sygn. 6, s. 12.

91 Zob. np. tamże, s. 64.

${ }_{92}$ Zob. np. AP Toruń, Kościół św. Jana, sygn. 9, k. 28r.

93 Zob. np. tamże, sygn. 10, k. 1r.

${ }_{94}$ Zob. np. tamże, k. 2r.

95 Zob. np. AP Toruń, Kościół św. Jana, sygn. 7, k. 54v; tamże, sygn. 10, k. 1r. Znany dotąd jedynie jako ławnik staromiejski w latach 1494-1500 i rajca staromiejski w latach 1500-1507: K. Mikulski, Urzędnicy miejscy Torunia. Spisy, t. 2: 1454-1650, Toruń 2001, s. 49-52, 124

${ }^{96}$ Zob. np. AP Toruń, Kościół św. Jana, sygn. 6, s. 41. Znany dotąd jedynie jako ławnik przedmiejski w latach 1497-1501 i staromiejski w latach 1501-1503: K. Mikulski, Urzędnicy, s. 125, 158.

${ }^{97}$ Zob. np. AP Toruń, Kościół św. Jana, sygn. 6, s. 65, 70, 71; tamże, sygn. 8, k. 14v, 16v, 58r; tamże, sygn. 9, k. 5v. Znany dotąd jedynie jako ławnik przedmiejski w latach 1504-1518: K. Mikulski, Urzędnicy, s. 159.

98 Zob. np. AP Toruń, Kościół św. Jana, sygn. 11, s. 25. Znany dotąd jedynie jako ławnik staromiejski (od 1501), rajca (od 1503), zarządca urzędu budowlanego (1503), wójt przedmiejski (1504, 1506), sędzia staromiejski (1505), kamlarz (1509), starszy rajca $(1511,1513,1516,1519,1522)$, zarządca piwnicy miejskiej (1517, 1518, 1519): K. Mikulski, Schottdorff Kasper, w: Toruński słownik biograficzny, t. 7, red. K. Mikulski, Toruń 2014, s. 197 n.

99 Zob. np. AP Toruń, Kościół św. Jana, sygn. 8, k. 66v; tamże, sygn. 10, k. 60r. Znany dotąd jedynie jako członek Trzeciego Ordynku w 1523 r.: K. Mikulski, Urzędnicy, s. 180. 
Vincenta Rudigera (1519-1523) ${ }^{100}$, Ludwiga Engelharta (1520-1523) $)^{101}$ i Hansa Hoffmana (1523-1553) ${ }^{102}$. Niektórzy podpisywali się jedynie przy okazji informacji o swoim wyborze. Inni częściej posługiwali się własnym nazwiskiem (zob. il. 2). Na marginesie dodajmy, że żaden z nich nie został dotychczas odnotowany jako witryk. Omawiane rachunki stanowią zatem ważne źródło do badań nad biografiami urzędników miejskich.

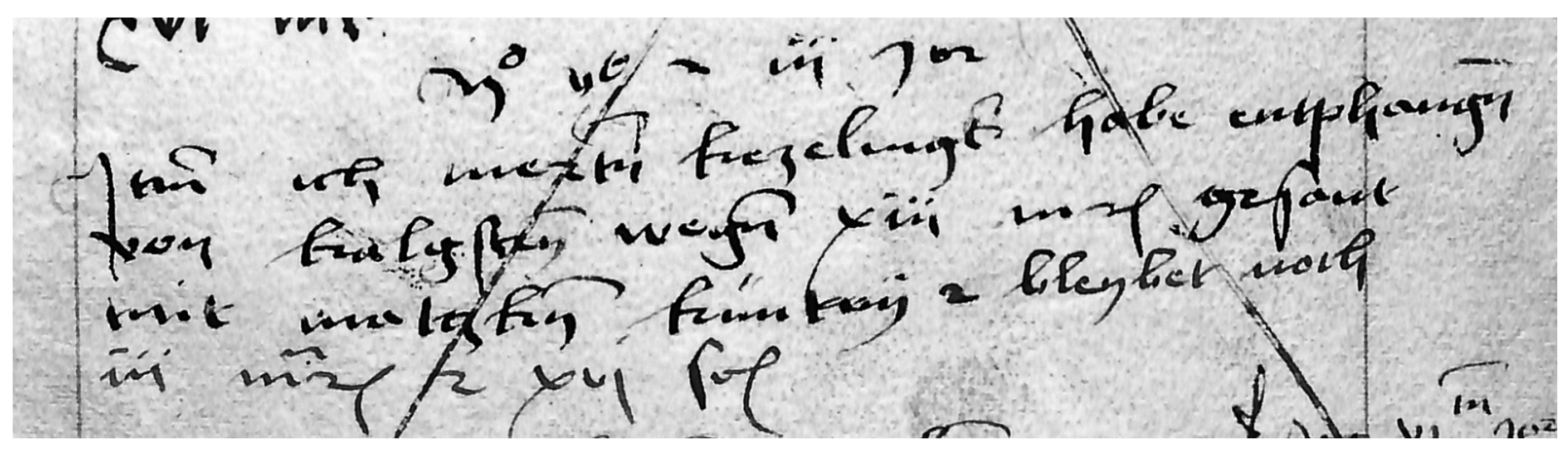

Il. 2. Wpis Martina Keszelinga; AP Toruń, Kościół św. Jana, sygn. 8, k. 14v

Omawiane rachunki poznajemy z osobistej perspektywy witryków, co nie jest bez znaczenia dla ich wartości poznawczej. Witryk sporządzał je z perspektywy czasu i w określonym celu. Samodzielnie ustalał układ i sposób prezentacji treści. Fundusz kościelny obserwujemy z jego punktu widzenia, a jego działania stanowią centralny temat wpisów ${ }^{103}$. Mimo że mamy do czynienia ze źródłami rachunkowymi, niektóre wpisy mają charakter egodokumentów ${ }^{104}$. Tego rodzaju wpisu dokonał w $1499 \mathrm{r}$. Nicolaus Kober, który informację o zakupie nieruchomości na rzecz kościoła adresował do swoich następców („Item wissetlichen sey allen kirchen fetern dy noch mir kamen”) ${ }^{105}$.

Charakterystyczne są wpisy informujące o wyborze piszącego na witryka. W 1503 r. dokonał go Martin Keszeling, określając się mianem niegodnego (,unwirdigk”) ${ }^{106}$. Georg Sweczgke, który został witrykiem w czasie kiery $1517 \mathrm{r}$., dwukrotnie zanotował to wydarzenie w prowadzonych przez siebie rachunkach. Dokonał tego w księdze czynszowej ${ }^{107}$ oraz w spisie przychodów ${ }^{108}$. W drugim wypadku miało to znaczenie z perspektywy przejęcia urzędu. Natomiast w księdze czynszowej wpis nie jest w żaden sposób powiązany z jej treścią. Notatka ma więc charakter memoratywny. Dwukrotnie o swoim wyborze poinformował również Vincent Rudiger ${ }^{109}$. Jego oba wpisy odnosiły się do przekazania mu pieniędzy kościoła i rejestrów. Określił w nich też swoje zadania, a więc pobieranie kościelnych czynszów i dalsze wydatki na budynek i potrzeby świątyni. Interesującego wpisu dokonał Ludwig Engelhart, który przejmował urząd w 1520 r. Nie tylko poinformował o jego objęciu, ale prosił Boga o zdrowie, rozum i mądrość konieczne do kierowania sprawami kościoła, a także liczył, że wypełnianie obowiązków

100 Zob. np. AP Toruń, Kościół św. Jana, sygn. 9, k. 49r, 58r; tamże, sygn. 10, k. 69r.

101 Tamże, sygn. 12, k. [0r]. Znany dotąd jedynie jako ławnik staromiejski w latach 1511-1519 i rajca staromiejski w latach 1519-1523: K. Mikulski, Urzędnicy, s. 58-60, 127.

102 AP Toruń, Kościół św. Jana, sygn. 12, k. 28r. Znany dotąd jedynie jako ławnik staromiejski w latach 1522-1531 i rajca staromiejski w latach 1531-1557: K. Mikulski, Urzędnicy, s. 64-75, 128.

${ }_{103}$ Por. M. Sumowski, Rachunki witryka, s. 247.

104 Zob. np. Selbstzeugnisse im polnischen und deutschen Schrifttum im Spätmittelalter und in der Frühen Neuzeit (15.-18. Jahrhundert), wyd. R. Skowrońska, H. Flachenecker, R. Czaja, S. Roszak, J. Tandecki, Toruń 2014.

105 AP Toruń, Kościół św. Jana, sygn. 8, k. 35v.

106 Tamże, k. 16v.

107 Tamże, k. 66v.

108 AP Toruń, Kościół św. Jana, sygn. 10, k. 60r.

109 Tamże, sygn. 9, k. 49r; tamże, sygn. 10, k. 69r. 
witryka pomoże mu w osiągnięciu życia wiecznego ${ }^{110}$. Podobnej formuły użył trzy lata później zastępujący go Hans Hoffman ${ }^{111}$.

Zasadnicza większość omawianych rachunków została sporządzona w języku niemieckim. Witrycy używali języka, jakim posługiwali się na co dzień, stosując jedynie łacińskie zwroty Item, dedit czy tenetur oraz datację opierającą się na świętach kościelnych. Odejście od łaciny w sporządzaniu rachunków kościołów notuje się również w miastach niemieckich w drugiej połowie XV i początkach XVI w., a zatem $\mathrm{w}$ okresie, z którego pochodzi większość toruńskich rejestrów ${ }^{112}$. Wyjątek stanowi sygn. 13, spisana zasadniczo w języku łacińskim, z nielicznymi tylko wpisami niemieckimi ${ }^{113}$.

Imienne wpisy witryków ułatwiają identyfikację rąk pisarskich. Zwykle są one łatwe do rozróżnienia, co pozwala przypisywać dany dukt pisma do konkretnej, podpisanej w innym miejscu osoby. Wyjątkiem są dwa zamieszczone na tej samej stronie pierwszoosobowe wpisy Georga Sweczgke (z 1517 i 1518 r.), z pewnością zapisane różnymi rękoma ${ }^{114}$. Pierwszy wpis jest tożsamy z duktem pisma tego witryka, znanym z innych rachunków. Drugi sporządziła zapewne inna osoba, być może na podstawie jego notatek (zob. niżej). Omawiane źródła charakteryzuje obecność znacznej liczby rąk pisarskich. Wynika to z dużej rozpiętości chronologicznej, jak również niejednolitej budowy. W przypadku jednostek złożonych z wtórnie połączonych składek zmiana ręki pisarskiej następuje zwykle wraz z nową składką (sygn. 6). W obrębie składki obok ręki wiodącej występują jednak liczne dopiski lub kontynuacja wpisów (sygn. 7, 10, 13). Szczególnie dużą liczbą rąk pisarskich charakteryzują się rejestry czynszowe, co wynika z ich wieloletniego użytkowania. Z kolei sygn. 11 wyróżnia się jako prowadzona w całości jedną ręką przez witryka Caspara Schottdorffa. Okres jej prowadzenia (1509-1520) pokrywa się $\mathrm{z}$ czasem jego urzędowania ${ }^{115}$. Natomiast w sygn. 12 obserwujemy dwie ręce następujących po sobie witryków: Ludwiga Engelharta i Hansa Hoffmana.

Witrycy toruńscy stosowali cyfry rzymskie, wyjątkowo używając arabskich dla wpisania daty rocznej ${ }^{116}$. Daty zapisane cyframi arabskimi notujemy z większą regularnością dopiero od drugiej dekady XVI w. ${ }^{117}$ W tym okresie pojawiają się już sporadycznie cyfry arabskie we wpisach ${ }^{118}$. Na jednej z dołączonych kart znajdują się również wykonywane na nich obliczenia ${ }^{119}$. Witrycy odrębnie prowadzili zestawienia przychodów i wydatków, ale mamy w tych rachunkach do czynienia z księgowością pojedynczą, nie podwójną ${ }^{120}$. Równoległe zestawienia ogólne $\mathrm{z}$ całego roku obserwujemy dopiero od $1523 \mathrm{r}^{121}$

Szczegółowa organizacja wpisów w omawianych źródłach uzależniona była natomiast od ich treści. Spisy przychodów i wydatków prawdopodobnie nie były prowadzone na bieżąco. Witryk uzupełniał je zapewne przed dokonaniem sprawozdania na podstawie wcześniejszych notatek ${ }^{122}$. Podobnie jak w przypadku rachunków innych urzędów miejskich, analogicznie zorganizowanych, stanowią one zwykle

110 Tamże, sygn. 12, k. [0r].

111 Tamże, k. 28 r.

112 A. Reitemeier, Pfarrkirchen in der Stadt, s. 38.

113 AP Toruń, Kościół św. Jana, sygn. 13, s. 19, 36 n., 39, 47, 60-63.

114 Tamże, sygn. 10, k. 60r.

115 Wybór na witryka (30 VII 1509): tamże, sygn. 11, s. 3. Wybór nowego witryka na jego miejsce (27 II 1520): tamże, sygn. 12, k. [0r].

116 Por. A. Reitemeier, Pfarrkirchen in der Stadt, s. 39 n.

117 AP Toruń, Kościół św. Jana, sygn. 6, s. 101-117, 134-159; tamże, sygn. 8, k. 28r, 34v; tamże, sygn. 9, k. 26r, 27r-38r, 49v, 52r, 58v-60v, 68r, 69r-70r; tamże, sygn. 10, k. 17v, 60r, 67r, 69r-74r, 80r, 81v, 90r, 96r-102v; tamże, sygn. 11, passim; tamże, sygn. 12, passim; tamże, sygn. 13, passim. Daty pisane cyframi arabskimi pojawiają się kilkakrotnie w latach 90. XV w.: tamże, sygn. 7, k. 28r, 32r-35r. W jednym wypadku mamy do czynienia z podwójnym zapisem, za pomocą obu systemów, rzymskiego i arabskiego: tamże, k. 41r. Por. późniejszy odpis tego fragmentu, gdzie również dwukrotnie zapisano rok: AP Toruń, Kościół św. Jana, sygn. 6, s. 123.

118 Tamże, sygn. 9, k. 50r.

119 Tamże, sygn. 10, k. 125v.

120 Por. M. Sumowski, Rachunki witryka, s. 246.

121 AP Toruń, Kościół św. Jana, sygn. 6, s. 134-159.

122 Por. J. Tandecki, Średniowieczne księgi wielkich miast pruskich, s. 219 n. 
czystopisy, z dołączonymi niekiedy kartami i składkami stosowanymi w bieżącym urzędowaniu ${ }^{123}$. Nicolaus Kober przedstawił takie rozliczenie choćby w 1501 r. (sygn. 10) ${ }^{124}$. Na oddzielnej składce zanotował najpierw wpływy do kasy kościoła (k. 1r-5v), a następnie wydatki (k. 7r-17v). Zastosował ponadto zabieg sumowania kwot $\mathrm{u}$ dołu każdej zapisanej strony. Podobnie uczynił Martin Keszeling w spisach przychodów ${ }^{125}$ i wydatków ${ }^{126} \mathrm{z}$ okresu sprawowania funkcji czy Vincent Rudiger ${ }^{127}$. Niezapisane karty danej składki mogły posłużyć kolejnym witrykom. Cytowany rejestr Kobera kontynuował jego następca na urzędzie, Hans Gore ${ }^{128}$.

$\mathrm{Na}$ sporządzanie spisów przed rozliczeniem z radą miejską zdaje się wskazywać również jednolity dla całego roku dukt pisma, a także obecność w omawianych jednostkach luźnych lub doklejonych czy wszytych kartek ${ }^{129}$. Niektóre $\mathrm{z}$ nich nie są paginowane, znajdują się między kartami rachunków (zob. il. 3$)^{130}$. Być może właśnie one stanowiły pierwotne notatki. Ciekawą wzmiankę dotyczącą sporządzania wpisów znajdziemy w księdze czynszowej. Jeden z witryków zanotował, że kiedy w 1496 r. przejął po poprzedniku księgi, odnalazł jego zapisy dotyczące długów na rzecz kościoła, które wprowadził do wykazu ${ }^{131}$.

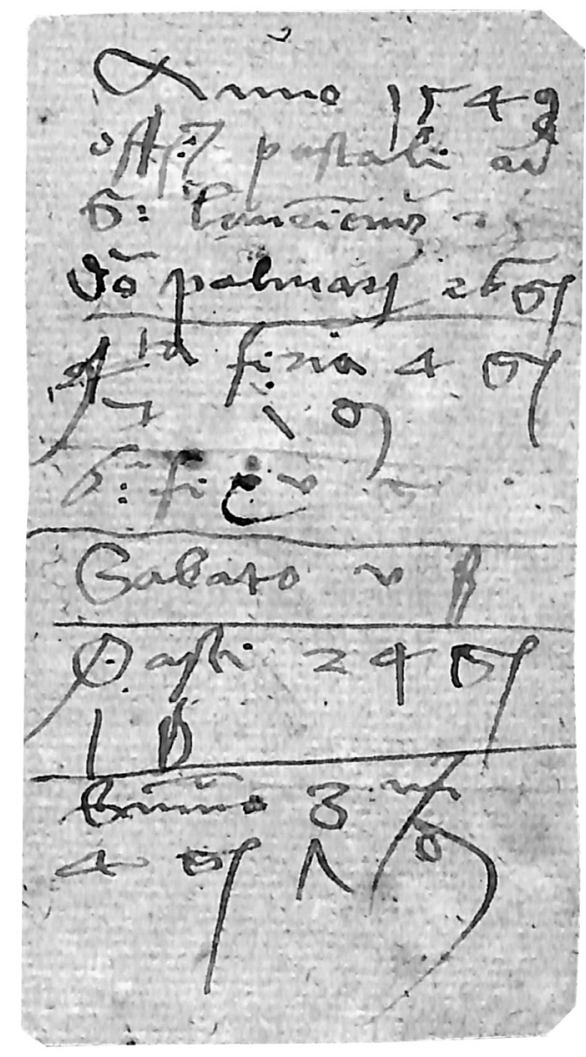

Il. 3. Luźna kartka; AP Toruń, Kościół św. Jana, sygn. 13, między s. 46 a 47

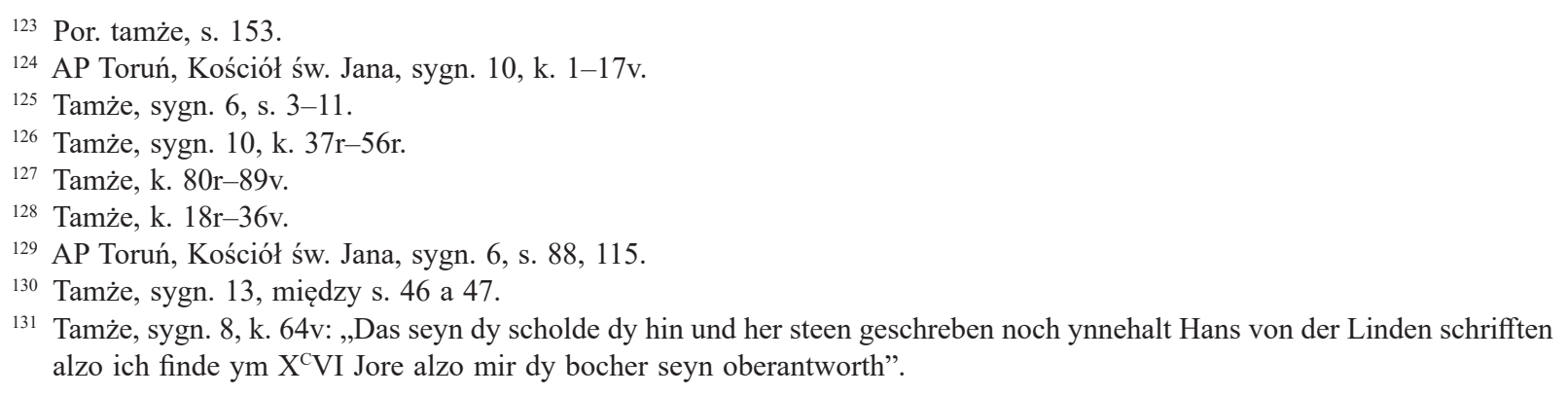


Rejestry czynszowe były jednak zorganizowane w sposób odmienny od materiałów stricte rachunkowych. Dobrym przykładem jest tu księga czynszowa (sygn. 8), której użytkowanie, na obecnym etapie badań, można podzielić na dwie fazy. Pierwsza wiązała się z jej założeniem w $1468 \mathrm{r}$. Zapewne z tego czasu pochodzą wyraźnie wyróżnione dane o płatnikach. Być może część księgi miała pełnić funkcję wykazu zobowiązań czynszowych, część natomiast rejestru wpłat. W drugiej fazie, ok. 1495 r., na wolnych kartach umieszczono nowe zobowiązania czynszowe, których nagłówki nie wyróżniają się od pozostałych wpisów (zob. il. 4 i 5). Księgę cechuje uporządkowanie przestrzeni pisarskiej z zachowaniem miejsca przeznaczonego na kolejne wpisy o wpłatach ${ }^{132}$.

Analogicznie zostały zorganizowane rejestry czynszowe z Siemonia. Wieś ta należała do kościoła od 1485 r. ${ }^{133}$ System czynszów na rzecz świątyni opierał się jednak na przywileju wystawionym dla chłopów przez poprzedniego właściciela wsi, burmistrza toruńskiego Rudigera von Birken w 1468 r. Odpis tego przywileju rozpoczyna pierwszy rejestr czynszowy, sporządzony w $1495 \mathrm{r}^{134}$ Stanowi on odrębną składkę sygn. 7 (k. 41-54). Na informacje o płatniku i wnoszonych przez niego należnościach przeznaczono dwie położone obok siebie strony. Pierwszą zajmowało nazwisko i dane o wysokości zobowiązań, drugą natomiast wpisy o dokonywanych opłatach. Schemat sporządzonych pierwotnie nagłówków, sukcesywnie uzupełnianych o informacje o wpłatach, zastosowano również w sygn. 9, zawierającej czynsze z Siemonia z lat 1516-1525 (k. 7r-39r). W związku z ich kilkuletnim użytkowaniem i zmianami witryków w przypadku rejestrów czynszowych zmiana ręki pisarskiej następuje w obrębie jednej strony, niekiedy kilkakrotnie (zob. il. 6).

Zamieszczane w omawianych źródłach wpisy wychodziły poza tematykę rejestru przychodów i wydatków lub czynszów. Jak wspominaliśmy na początku, do kościelnej rachunkowości włączone zostały inwentarze. Jeden z nich stanowi spis ornatów należących do kaplicy Dreybecherów, sporządzony w 1490 r. ${ }^{135}$ Rozpoczyna on pierwszą składkę sygn. 6 (s. 1-28). Dalej zostały wpisane przychody kościoła z początku XVI w., a zatem można zakładać, że składka przeznaczona pierwotnie na inwentarz została później wykorzystana do sporządzenia rejestru rachunkowego. Drugi z inwentarzy stanowi spis sprzętów należących do kościoła ${ }^{136}$. Materiałem nierachunkowym jest również dołączona na arkuszu doszytym do ostatniej składki sygn. 10 ordynacja dla dzwonników (k. 121r-123r). Wpisy tego rodzaju są wyraźnie wyodrębnione w stosunku do pozostałych. W materiałach rachunkowych znalazły się zapewne jako część dokumentacji funkcjonowania parafii.

W omawianych źródłach występują również inne wpisy, niedotyczące bezpośrednio przychodów i wydatków, ale dokumentujące finansową działalność fabricae ecclesiae. Dobrym przykładem są regulacje dłużne między radą miejską a funduszem kościelnym z lat 1500 i 1510, wpisane na jednej z kart księgi czynszowej ${ }^{137}$. Część wpisów miała natomiast charakter poświadczenia transakcji dokonywanych przez witryków ${ }^{138}$. Istnieją pewne zależności między omawianymi rejestrami rachunkowymi a księgami miejskimi. Wpisy dokonywane przez witryków zawierały niekiedy informację o odnotowaniu danej sprawy w księgach ławniczych czy radzieckich. W księdze czynszowej zanotowano transakcję kupna domu z 1476 r., informując jednocześnie o takich adnotacjach (,so im scheppen buche gescreben ist unde och uff dem ro<e>thawssze") ${ }^{139}$. Istotnie wpis taki znajduje się w księdze ławniczej ${ }^{140}$.

\footnotetext{
132 Szersze rozważania na temat czynszów i ich topografii oraz płatników znajdą się we wstępie do edycji przygotowywanej w ramach projektu.

133 Słownik historyczno-geograficzny ziemi chetmińskiej w średniowieczu, oprac. K. Porębska, współpr. M. Grzegorz, red. M. Biskup, Wrocław 1971, s. 116.

134 AP Toruń, Kościół św. Jana, sygn. 7, k. 41r i n. Na podstawie tego odpisu sporządzono późniejszą kopię, przepisaną na jednej składce, która została włączona do: tamże, sygn. 6, s. 123-130.

135 Tamże, sygn. 6, s. 1.

136 Tamże, sygn. 13, s. 21-23.

137 Tamże, sygn. 8, k. 66r.

138 Zob. np. tamże, k. 48r, 53r, 57r.

139 Tamże, k. 89v.

${ }^{140}$ Księga ławnicza Starego Miasta Torunia (1456-1479), wyd. K. Kopiński, J. Tandecki, Toruń 2007, nr 1364.
} 


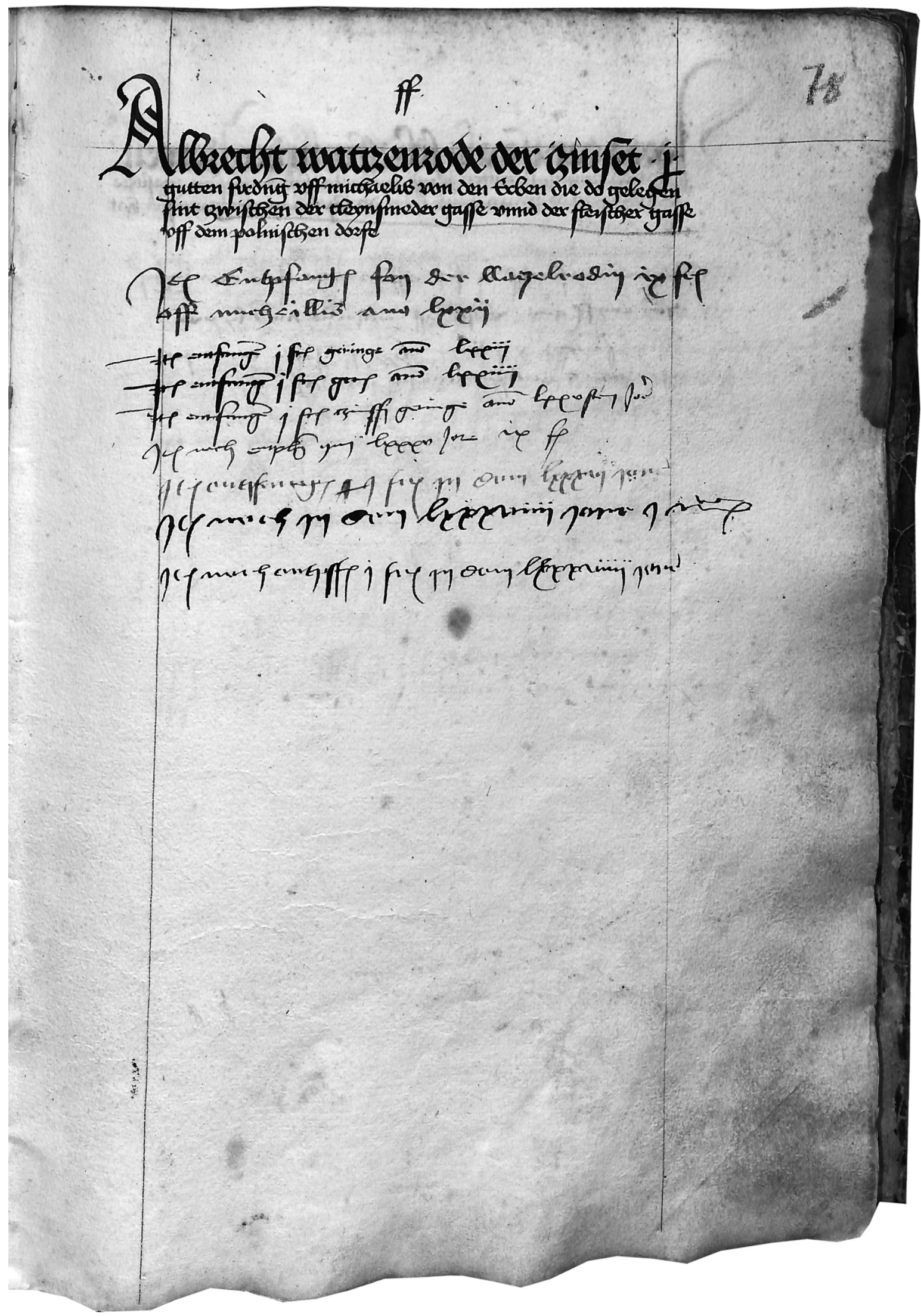

Il. 4. Wpisy dotyczące czynszu Albrechta Watczenrode; AP Toruń, Kościół św. Jana, sygn. 8, k. 78r 


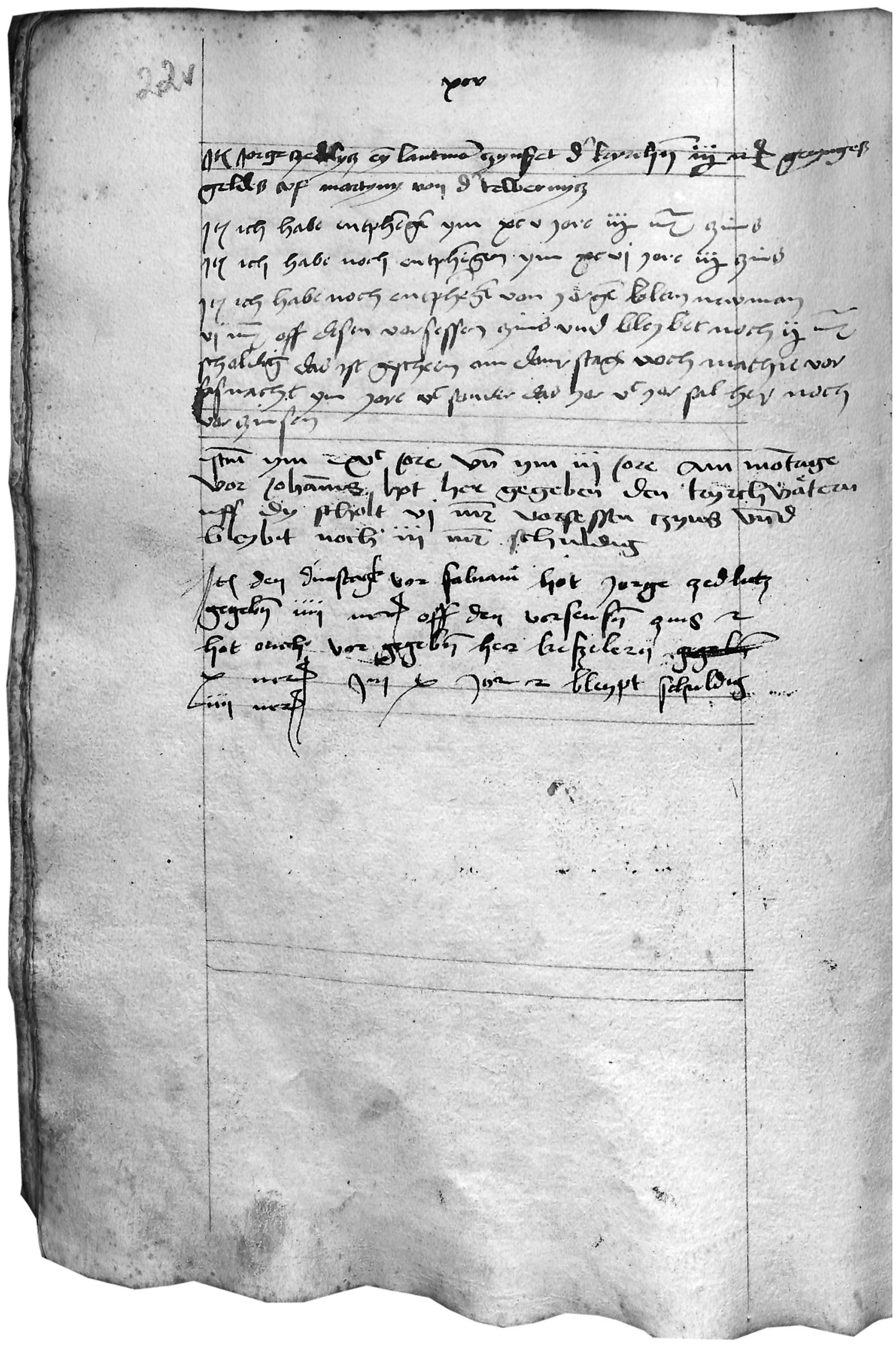

Il. 5. Wpisy dotyczące czynszu Jorgego Czedlycza; AP Toruń, Kościół św. Jana, sygn. 8, k. 22v 


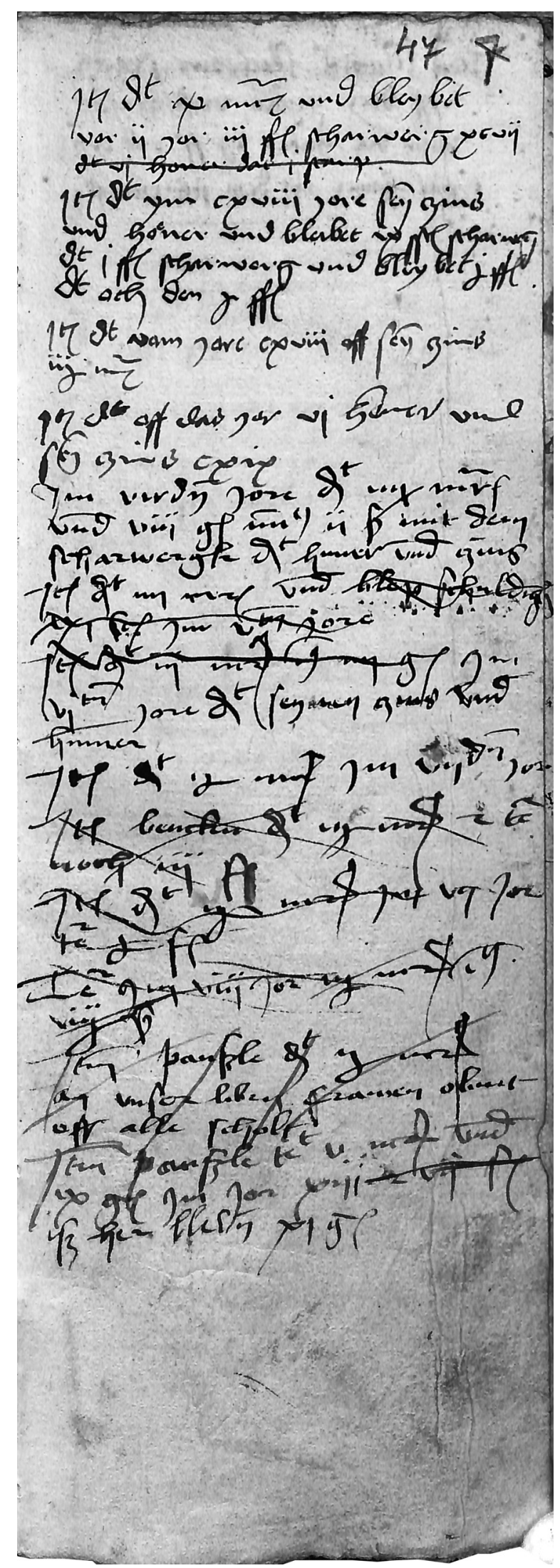

Il. 6. Pismo Nicolausa Kobera (wpisy z lat 1497-1499) i Martina Keszelinga (wpisy z lat 1504-1513) w spisie czynszów z Siemonia; AP Toruń, Kościół św. Jana, sygn. 7, k. 47r 


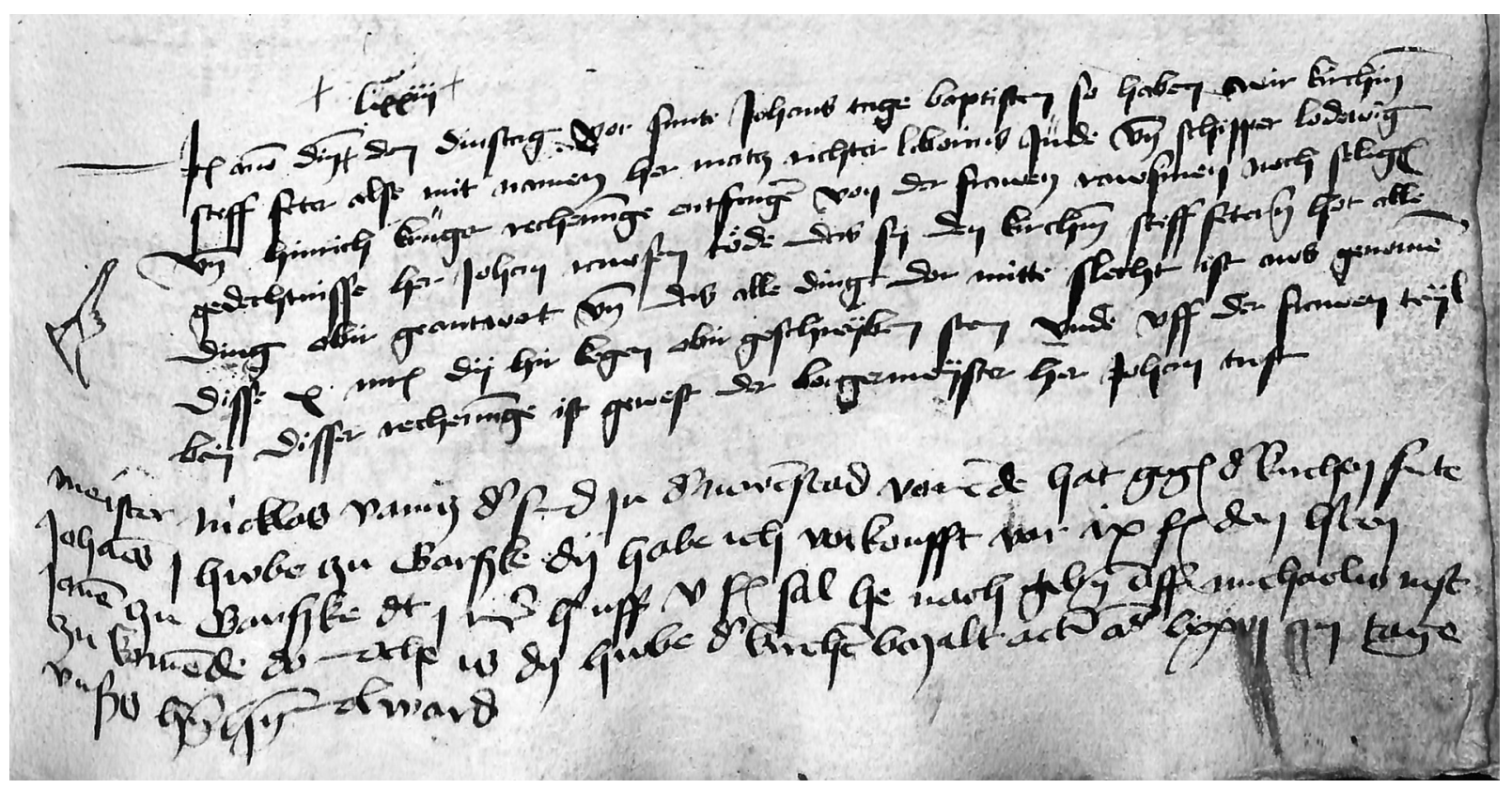

Il. 7. Oznaczenie wpisu rączką; AP Toruń, Kościół św. Jana, sygn. 8, k. 53r

Analogiczne notatki, informujące o wpisach w staromiejskiej księdze ławniczej, pochodzą z $1495^{141}$, $1497^{142}$ oraz 1507 r. ${ }^{143} \mathrm{Z}$ kolei w 1499 r. witryk informował o odnotowaniu transakcji w księdze sądu przedmiejskiego Nowego Miasta Torunia ${ }^{144}$. Wpis z 1504 r. miał zostać natomiast powtórzony w księdze rady (,noch ym alz denne vorschreiben isz off dem rothausze” $)^{145}$. W transakcji z $1508 \mathrm{r}$. wspomina się z kolei o jej wpisaniu do księgi nowomiejskiej (,vorschreben in der hern buche in der newstat") ${ }^{146}$. Podobny wpis, dotyczący przedmieść, odnotowano dwa lata później (,vorschreben in der hern buch vor der stath" $)^{147}$.

$\mathrm{Z}$ powtórzeniem wpisu mamy też do czynienia w przypadku testamentu plebana z $1483 \mathrm{r}$. Duchowny zamieścił akt swojej ostatniej woli w prywatnych zapiskach, informując, że znajduje się on również w księgach miejskich i kościelnych („Dergleichen schrifte steen in des rates buche und in der kirchen buche") ${ }^{148}$. Testament został rzeczywiście wpisany na jednej z ostatnich kart księgi czynszowej. Tam z kolei znalazła się adnotacja o jego powtórzeniu w księdze radzieckiej („das ouch ÿn des rates buch is geschreben") $)^{149}$.

Wszystkie cytowane wzmianki dotyczące powtórzeń wpisów pochodzą z księgi czynszowej (sygn. 8). Zabiegi te wynikały zapewne z jej przeznaczenia do wieloletniego użytkowania, co gwarantowało jej trwałość. Było to również pochodną omawianej wyżej organizacji wpisów, które w tej księdze odnoszą się do konkretnych działek. Odpowiednie uporządkowanie, także wizualne, treści ułatwiało bieżące korzystanie $\mathrm{z}$ rejestrów ${ }^{150}$. Wpisy czynszowe zawierały informacje o zmianie właściciela, zmianie lub

\footnotetext{
${ }^{141}$ AP Toruń, Kościół św. Jana, sygn. 8, k. 90r; Księga ławnicza Starego Miasta Torunia (1479-1515), cz. 1, nr 925.

${ }_{142}$ AP Toruń, Kościół św. Jana, sygn. 8, k. 28v; Księga ławnicza Starego Miasta Torunia (1479-1515), cz. 1, nr 1054.

143 AP Toruń, Kościół św. Jana, sygn. 8, k. 39v; Księga ławnicza Starego Miasta Torunia (1479-1515), cz. 2: 1502-1515, wyd. K. Kopiński, K. Mikulski, J. Tandecki, Toruń 2018, nr 1858.

144 AP Toruń, Kościół św. Jana, sygn. 8, k. 35v

145 Tamże, k. 38v

146 Tamże, k. 43v

147 Tamże, k. 21v.

148 Die Aufzeichnungen des Thorner Pfarrers Hieronymus Waldau, wyd. O. Günther, „Zeitschrift des Westpreussischen Geschichtsvereins", 49, 1907, s. 228 n.

149 AP Toruń, Kościół św. Jana, sygn. 8, k. 90v.

${ }^{150}$ Por. M. Grulkowski, Najstarsze księgi gruntowe, s. 195-199.
} 
ustaniu zobowiązania, co wynikało z zasadniczej funkcji tej księgi, a więc przydatności przy ściąganiu należności. Nie tylko tego rodzaju spisy posiadały jednak cechy mające ułatwić późniejsze korzystanie. Dla lepszej orientacji w tekście witrycy stosowali rysowane na marginesie rączki do oznaczenia wybranych wpisów, choć czynili to bardzo rzadko w skali całego analizowanego materiału (il. 7) ${ }^{151}$. W sygn. 11 występują ponadto pergaminowe zakładki ułatwiające odnalezienie wpisów z danego $\mathrm{roku}^{152}$. Śladami po bieżącym użytkowaniu są również liczne skreślenia i dopiski, występujące w niemal wszystkich omawianych źródłach.

Rachunki kościoła św. Jana w Toruniu są znakomitym przykładem funkcjonowania funduszu kościelnego (fabrica ecclesiae) w późnośredniowiecznym mieście. Dają pewne wyobrażenie o życiu codziennym parafii i dokumentują działalność witryków. Wydaje się, że omawiany materiał rachunkowy należy traktować jako źródła miejskie, wytwór jednego z urzędów miejskich. Cechuje je duże zróżnicowanie formy i treści. Z kolei ich rozpiętość chronologiczna oraz szeroka tematyka wpisów dają duże możliwości badawcze. Dalsze analizy, w tym kodykologiczne, z pewnością przyniosą wartościowe poznawczo rezultaty.

$* * *$

Niniejsza prezentacja rachunków kościoła Świętojańskiego stanowi część projektu edytorskiego „Średniowieczne rachunki kościołów toruńskich - opracowanie, edycja, digitalizacja”, realizowanego pod kierunkiem prof. Piotra Olińskiego ${ }^{153}$. W jego ramach planowana jest również cyfrowa edycja, połączona $\mathrm{z}$ udostępnieniem fotografii oryginałów ${ }^{154}$. Przedstawione rozważania mają charakter wstępny. Powstały na marginesie prac badawczo-edytorskich. Planowany jest rozbudowany wstęp do edycji książkowej, w którym zostaną rozwinięte zasygnalizowane wyżej problemy oraz zweryfikowane przedstawione hipotezy.

\section{Medieval accounts of St John's Church in Toruń. Source studies remarks}

Summary: The article presents and examines from the perspective of source studies medieval accounts of St John's Church in Torun. The set of financial records is made up of eight archival units kept in the State Archives in Torun. Their chronological scope spans the period from the first half of the $15^{\text {th }}$ to the mid- $16^{\text {th }}$ century. They document the operation of the office responsible for a parish church (fabrica ecclesiae), headed by a lay administrator (sexton) called vitricus (ger. Kirchenvater, pol. witryk). The Torun accounts are varied both in terms of their form and content. Some of them are in the form of a book; some are in the form of a fascicule, made up of folios subsequently bound together. The account registers consist of rent lists, income and expenditure specifications, construction bills, vitricus' settlements with the municipal council, stock inventories, and an ordinance for bell-ringers. The accounts were kept personally by vitricus, as is indicated by the first-person narrative. This makes it possible to regard the analysed sources as egodocuments. A characteristic feature of the registers is the presence of numerous writing hands which evidences many years of their usage. Registers of this type were organised to secure their long-lasting. They were intended for the current use, and for this reason, information about changes in the payment status was recorded. There is also a correlation between the accounts and other municipal sources, expressed in the duplication of entries. The analysed financial records are an excellent source for the study of the day-to-day functioning of the municipal parish.

${ }^{151}$ AP Toruń, Kościół św. Jana, sygn. 8, k. 52v, 53r; tamże, sygn. 13, s. 2.

152 Tamże, sygn. 11, s. 6, 22, 44.

153 Zob. prezentację projektu: A. Sumowska, M. Sumowski, Die mittelalterlichen Rechnungen der Thorner Kirchen - Bearbeitung, Edition, Digitalisierung. Vorstellung eines Projektes, w: Editionswissenschaftliches Kolloquium 2019. Urkundenbücher, Chroniken, Amtsbücher. Alte und neue Editionsmethoden (w druku).

${ }^{154}$ Zob. prezentację internetowej bazy rachunków: M. Sumowski, Cyfrowa edycja średniowiecznych rachunków kościołów toruńskich, w: Editiones sine fine, t. 2 (w druku). 
Nota o autorze: Alicja Sumowska, dr, ur. 1988, absolwentka Wydziału Nauk Historycznych Uniwersytetu Mikołaja Kopernika w Toruniu (2012), doktor nauk humanistycznych w zakresie historii (2018); jej rozprawa doktorska poświęcona została relacjom rycerstwa ziemi chełmińskiej z zakonem krzyżackim w pierwszej połowie XV w. Od 2019 r. asystent muzealny w Muzeum Okręgowym w Toruniu, w Dziale Historii i Dziejów Miasta Torunia. Stypendystka Polskiej Misji Historycznej w Würzburgu, Fundacji Lanckorońskich oraz Stiftung Preußischer Kulturbesitz. Jest członkiem zespołu badawczego realizującego projekt „Średniowieczne rachunki kościołów toruńskich - opracowanie, edycja, digitalizacja" (NCN OPUS). Jej zainteresowania badawcze skupiają się wokół historii społecznej, dziejów Torunia i ziemi chełmińskiej w średniowieczu.

Author: Alicja Sumowska, PhD, b. 1988, graduate of the Faculty of History, Nicolaus Copernicus University in Torun (2012), PhD in humanities in the field of history (2018); her doctoral thesis was on the relationship between the knights of the Chelmno Land and the Teutonic Order in the first half of the $15^{\text {th }}$ century. Since 2019 she is an assistant at the District Museum in Toruń, the Department of the History of the Town of Toruń; scholarship holder of the Polish Historical Mission at the University of Julius Maximilian in Würzburg, The Lanckoronski Foundation, and the Prussian Cultural Heritage Foundation. Member of the research team for the project 'Medieval accounts of Torun's churches - study, edition, digitalization' (NCN OPUS). Her research interests focus on social history, history of Toruń and Chełmno Land in the Middle Ages.

Nota o autorze: Marcin Sumowski, dr, ur. 1987, absolwent Wydziału Nauk Historycznych Uniwersytetu Mikołaja Kopernika w Toruniu (2011), doktor nauk humanistycznych w zakresie historii (2018); jego praca doktorska poświęcona była miejscu kleru niższego w społeczeństwie późnośredniowiecznych miast pruskich. Od 2018 r. zatrudniony w Pracowni Słownika Historyczno-Geograficznego Prus Średniowiecznych na Wydziale Nauk Historycznych UMK. Stypendysta Polskiej Misji Historycznej w Würzburgu, Fundacji Lanckorońskich oraz Stiftung Preußischer Kulturbesitz. W 2018 r. otrzymał stypendium START Fundacji na rzecz Nauki Polskiej. Kierownik i członek zespołów badawczych realizujących projekty naukowe w ramach grantów NCN i NPRH. Zainteresowania naukowe: historia społeczna, niższe duchowieństwo średniowieczne, edytorstwo źródeł historycznych.

Author: Marcin Sumowski, PhD, b. 1987, graduate of the Faculty of History, Nicolaus Copernicus University in Torun (2011), PhD in humanities in the field of history (2018); his doctoral thesis was devoted to the place of the lower clergy within the community of late-medieval Prussian towns; since 2018 employee of the Laboratory for Historical and Geographical Dictionary of Mediaeval Prussia at the Faculty of History, Nicolaus Copernicus University in Torun; scholarship holder of the Polish Historical Mission at the University of Julius Maximilian in Würzburg, The Lanckoronski Foundation, and the Prussian Cultural Heritage Foundation; in 2018, he was granted the START programme of the Foundation for Polish Science; head and member of research teams carrying out scholarly projects financed by the grants of the National Science Centre and the National Programme for the Development of the Humanities; his research interests include: social history, lower medieval clergy, academic editing of historical sources.

Pracownia Słownika Historyczno-Geograficznego Prus Średniowiecznych

Instytut Historii i Archiwistyki

Wydział Nauk Historycznych

Uniwersytet Mikołaja Kopernika w Toruniu

ul. Bojarskiego 1

87-100 Toruń

e-mail: m.sumowski@gmail.com

\section{Bibliografia}

\section{Źródła}

Die Aufzeichnungen des Thorner Pfarrers Hieronymus Waldau, wyd. O. Günther, „Zeitschrift des Westpreussischen Geschichtsvereins", 49, 1907, s. 221-251

Constitutiones synodales necnon ordinationes dioecesis Culmensis, cz. 1, wyd. A. Mańkowski, „Fontes Towarzystwa Naukowego w Toruniu", 24, 1929 
Constitutiones synodales Warmienses, Sambienses, Pomesanienses, Culmenses necnon provinciales Rigenses, wyd. F. Hipler, Brunsbergae 1899 [tłum. Statuty synodalne Warmińskie, Sambijskie, Pomezańskie, Chetmińskie oraz Prowincjalne Ryskie, tłum. J. Wojtkowski, Olsztyn 2010]

Czyżak M., Radzimiński A., Earliest Synod Statutes of John Marienau, Bishop of Chetmno, from the First Half of $15^{\text {th }}$ Century, „Quaestiones Medii Aevi Novae”, 24, 2019, s. 111-135

Dzieje i skarby kościoła świętojańskiego w Toruniu, red. K. Kluczwajd, M. Woźniak, Toruń 2002

„Formularz z Uppsali”. Późnośredniowieczna księga formularzowa biskupstw pruskich, koment. i wyd. R. Biskup, Toruń 2016

Günther O., Eine Predigt vom preußischen Provinzialkonzil in Elbing 1427 und die „Ermahnung des Carthäusers”, „Zeitschrift des Westpreussischen Geschichtsvereins”, 59, 1919, s. 69-111

Księga czynszów fary chetmińskiej (1435-1496), wyd. Z.H. Nowak, J. Tandecki, Toruń 1994

Księga ławnicza Starego Miasta Torunia (1428-1456), cz. 1: 1428-1443, wyd. K. Ciesielska, J. Tandecki, Toruń 1992

Księga ławnicza Starego Miasta Torunia (1428-1456), cz. 2: 1444-1456, wyd. K. Ciesielska, J. Tandecki, Toruń 1993

Księga ławnicza Starego Miasta Torunia (1456-1479), wyd. K. Kopiński, J. Tandecki, Toruń 2007

Ksiega ławnicza Starego Miasta Torunia (1479-1515), cz. 1: 1479-1501, wyd. K. Kopiński, K. Mikulski, J. Tandecki, Toruń 2018

Księga ławnicza Starego Miasta Torunia (1479-1515), cz. 2: 1502-1515, wyd. K. Kopiński, K. Mikulski, J. Tandecki, Toruń 2018

Das Rößeler Pfarrbuch. Aufzeichnungen der Kirchenväter an der Pfarrkirche zu Rößelin den Jahren 1442 bis 1614, wyd. G. Matern, A. Birch-Hirschfeld, Braunsberg 1937

Urkundenbuch des Bisthums Culm, t. 1, oprac. C.P. Woelky, cz. 1, Danzig 1885

\section{Opracowania}

Czaja R., Urzędnicy miejscy Torunia. Spisy, cz. 1: Do roku 1454, Torun 1999

Editionswissenschaftliches Kolloquium 2009. Zahlen und Erinnerung: Von der Vielfalt der Rechnungsbücher und vergleichbarer Quellengattungen, wyd. H. Flachenecker, J. Tandecki, Toruń 2010

Grulkowski M., Definicja i klasyfikacje ksiag miejskich. Ksiegi w kancelariach miast obszaru Hanzy, w: Nauki pomocnicze historii. Teoria, metody badań, dydaktyka, red. A. Jaworska, R. Jop, Warszawa 2013, s. 119-148

Grulkowski M., Najstarsze księgi gruntowe Głównego Miasta Gdańska w XIV i XV wieku. Uwagi źródłoznawcze, w: Miasta polskie w średniowieczu i czasach nowożytnych, red. P. Gołdyn, Kraków 2008, s. 181-200

Grulkowski M., Najstarsze księgi miejskie Głównego Miasta Gdańska z XIV i początku XV wieku. Studium kodykologiczne, Warszawa 2015

Herrmann Ch., Witrycy kościoła Mariackiego w Gdańsku. Pozycja, zadania i działalność od XIV do początku XVII w., w: Chronik der Marienkirche in Danzig. Das „Historische Kirchen Register”von Eberhard Bötticher (1616). Transkription und Auswertung / Kronika kościoła Mariackiego w Gdańsku. „Historisches Kirchen Register” Eberharda Böttichera (1616). Transkrypcja i analiza, red. Ch. Herrmann, E. Kizik, Köln-Weimar-Wien 2013, s. 115-204

Kizik E., Historisches Kirchen Register - opis autografu oraz jego źródet, w: Chronik der Marienkirche in Danzig. Das „Historische Kirchen Register” von Eberhard Bötticher (1616). Transkription und Auswertung / Kronika kościoła Mariackiego w Gdańsku. „Historisches Kirchen Register” Eberharda Böttichera (1616). Transkrypcja $i$ analiza, red. Ch. Herrmann, E. Kizik, Köln-Weimar-Wien 2013, s. 287-312

Mikulski K., Schottdorff Kasper, w: Toruński słownik biograficzny, t. 7, red. K. Mikulski, Toruń 2014 , s. 197 n.

Mikulski K., Urzędnicy miejscy Torunia. Spisy, t. 2: 1454-1650, Toruń 2001

Radzimiński A., Piętnastowieczne rachunki plebanów z Torunia i Brodnicy jako źródła do badania dziejów parafii w państwie zakonu krzyżackiego w Prusach, Rocz. Hum., 48, 2000, nr 2, s. 473-482

Radzimiński A., Rachunki plebana kościoła parafialnego Świętych Janów w Starym Mieście Toruniu z lat 1445-1446, Rocz. Hist., 69, 2003, s. 167-187

Reitemeier A., Pfarrkirchen in der Stadt des späten Mittelalters: Politik, Wirtschaft und Verwaltung, Wiesbaden 2005

Rozynkowski W., Powstanie i rozwój sieci parafialnej w diecezji chetmińskiej w czasach panowania zakonu krzyżackiego, Toruń 2000

Semrau A., Der Bau des Kirchturms zu S. Johann in Thorn, „Mitteilungen des Coppernicus-Vereins für Wissenschaft und Kunst zu Thorn", 18, 1910, s. 27-39 
Semrau A., Forschungen zur Baugeschichte der Johanniskirche in Thorn von 1250 bis 1500, „Mitteilungen des Coppernicus-Vereins für Wissenschaft und Kunst zu Thorn", 21, 1913, nr 2, s. 28-53

Skierska I., Zarząd finansami parafii w późnośredniowiecznej Polsce, „Ecclesia. Studia z Dziejów Wielkopolski”, 8, 2013, s. 7-26

Słoń M., Blisko źródła czy Czytelnika? Refleksje na marginesie edycji rachunków szpitalnych z 1495 roku, St. Źródł., 45, 2007, s. 65-70

Słoń M., Średniowieczne rachunki szpitali wrocławskich, Kwart. Hist., 105, 1998, nr 2, s. 17-32

Sumowska A., Sumowski M., Die mittelalterlichen Rechnungen der Thorner Kirchen - Bearbeitung, Edition, Digitalisierung. Vorstellung eines Projektes, w: Editionswissenschaftliches Kolloquium 2019. Urkundenbücher, Chroniken, Amtsbücher. Alte und neue Editionsmethoden (w druku)

Sumowski M., Cyfrowa edycja średniowiecznych rachunków kościolów toruńskich, w: Editiones sine fine, t. 2 (w druku)

Sumowski M., „Pastor et oves” - Parish Priest in Late-Medieval Prussian Town, „Quaestiones Medii Aevii Novae", 23, 2018, s. 343-377

Sumowski M., Rachunki witryka kościoła św. Jakuba w Toruniu z 1468 roku, w: Parafie w średniowiecznych Prusach w czasach zakonu niemieckiego od XIII do XVI w., red. A. Radzimiński, R. Biskup, Toruń 2015, s. 237-271

Tandecki J., Średniowieczne księgi rachunkowe Starego Miasta Torunia i ich edycje, w: tenże, Szkice z dziejów Torunia i Prus w średniowieczu i na progu czasów nowożytnych, Toruń 2008, s. 103-117

Tandecki J., Średniowieczne księgi wielkich miast pruskich jako źródła historyczne i zabytki kultury mieszczańskiej (organizacja władz, zachowane archiwalia, działalność kancelarii), Warszawa-Toruń 1990

Wiśniowski E., Parafie w średniowiecznej Polsce. Struktura i funkcje społeczne, Lublin 2004

\section{Bazy danych}

Wasserzeichen-Informationssystem $<$ https://www.wasserzeichen-online.de $>$ 